\title{
Genetic Instability in Gastric Cancer
}

\author{
Petra Hudler, Matjaz Vogelsang and Radovan Komel \\ University of Ljubljana, Faculty of Medicine, Institute of Biochemistry, \\ Medical Centre for Molecular Biology and Department for Biosynthesis and \\ Biotransformation, National Institute of Chemistry \\ Slovenia
}

\section{Introduction}

Gastric cancer remains a worldwide burden as a second leading cause of cancer death in both sexes (Globocan, 2011; Nobili et al., 2011). Although its incidence is in decline in developed countries, it is still the fourth most common malignancy in the world, behind cancers of the lung, breast, colon, and rectum (Globocan, 2011). The fall in its incidence is attributed mainly to the decline of the intestinal type of stomach cancer, whereas the incidence of the diffuse type has remained constant over time (Yamashita et al., 2011). On the other hand, there has been a progressive increase in the cardia and gastroesophageal junction adenocarcinoma (Milne et al., 2009; Yamashita et al., 2011). The exact cause of this shift in location is not known. The general decrease of gastric cancer frequency in developed countries is attributed to the changes in dietary habits and food preservation methods (Crew \& Neugut, 2006; Kufe et al., 2003). The prevalence of gastric cancer varies throughout the world, with the highest rates reported in Korea, Japan, Central and South America, and Eastern Europe, whereas Western Europe, North America, Africa, Australia, and New Zealand are low incidence areas (Crew \& Neugut, 2006; Tahara, 2008; Yamashita et al., 2011). Despite the decrease in its incidence and improvements in diagnosis, curative surgery, and treatment, gastric cancer remains major health burden due to its poor prognosis (Smith et al., 2006; Yamashita et al., 2011).

Adenocarcinoma is the major histological type of gastric cancer; accounting for $90 \%$ to $95 \%$ of all gastric malignancies, and this chapter will focus only on this type of gastric tumours (Hamilton \& Meltzer, 2006). Adenocarcinoma develops from the glandular cells of stomach mucosa, while other rare stomach cancers develop in lymph tissue (lymphoma), hormone producing cells (carcinoid tumours), muscle cells (soft tissue sarcomas) or certain nerve cells (gastrointestinal stromal tumours or GIST) (Smith et al., 2006). Based on the widely used Lauren classification, adenocarcinomas are divided into two distinct pathological entities, intestinal and diffuse types, which have different clinicopathological and prognostic features (Yamashita et al., 2011). Intestinal type is associated with Helicobacter pylori infection, obesity and certain dietary factors, such as high intake of salt, smoked meats and food preserved with nitrites or nitrates, and is believed to arise through a long-term multistep progression from chronic gastritis to chronic atrophy to intestinal metaplasia to dysplasia (Crew \& Neugut, 2006; Hamilton \& Meltzer, 2006; Yamashita et al., 2011). Histologically it is well differentiated and occurs more commonly in older patients, males and blacks (Crew \& Neugut, 2006). Diffuse type is poorly differentiated with infiltrating, 
non-cohesive cells and is more frequent in younger patients (Crew \& Neugut, 2006; Panani, 2008). Studies showed that Helicobacter pylori infection also plays a role in the development of diffuse gastric cancer, through chronic inflammation, but without occurrence of intermediate steps, such as gastric atrophy and intestinal metaplasia (Milne et al., 2009).

It is believed that the pathogenesis of gastric cancer represents a classic example of geneenvironment interactions (Panani, 2008). Epidemiologic studies have shown a reduction of its incidence in migrant populations, when they move from high-risk areas to low-incidence ones. Subsequent populations acquire risk levels similar to those in the host country, indicating the importance of environmental influences on its development (Crew \& Neugut, 2006; Matysiak-Budnik \& Megraud, 2006). Therefore, it is generally acknowledged that both, environmental and genetic factors are implicated in the pathogenesis of gastric cancer development (Milne et al., 2009). Furthermore, several researchers believe that environmental factors have a greater influence on the development of intestinal type, whereas diffuse type might have a stronger genetic background (Matysiak-Budnik \& Megraud, 2006; Milne et al., 2009). Nevertheless, despite tremendous efforts in the past few decades, there is still no clear agreement on the genetic and epigenetic changes underlying the initiation and progression of both types of gastric adenocarcinoma (Milne et al., 2009; Panani, 2008).

This review is intended to focus on different molecular hypotheses of gastric carcinogenesis. New advances in the fields of high-throughput methodologies, functional genomics and molecular profiling will be discussed.

\section{Molecular mechanisms of gastric carcinogenesis}

Numerous cytogenetic and molecular genetic studies tested common cancer hypotheses, such as oncogene overexpression, suppressor, mutator, and methylator pathway hypotheses, but exact molecular mechanisms of gastric cancer development remain elusive. In nearly two decades of research a vast amount of articles referring to overexpression and silencing of genes was published (Resende et al., 2010). Several studies reported amplification and overexpression of growth factors, growth factor receptors, tyrosine kinases, nuclear factors, matrix metalloproteinases, cell cycle regulators cytokines and other genes (Panani, 2008; Tahara, 2008; Wu et al., 2010). Furthermore, other studies have shown that loss of heterozigosity ( $\mathrm{LOH})$ and inactivation of tumour suppressor genes seem to be involved in the development of gastric adenocarcinomas (Gazvoda et al., 2007; Juvan et al., 2007; Panani, 2008; Resende et al., 2010). The presence of spontaneous DNA replication errors in simple repetitive microsatellite sequences indicated a novel pathway of carcinogenesis, microsatellite instability (MSI) (Loeb, 2001; Panani, 2008; Simpson et al., 2001). It was found that it could be the consequence of defective DNA mismatch repair mechanism (MMR), caused by genetic alterations in MLH1, MSH2, PMS1, and PMS2 genes (Hudler et al., 2004; Loeb, 2001; Panani, 2008; Simpson et al., 2001). In recent years, epigenetic changes, such as promoter methylation, hypomethylation and histone acetylation have been also recognized in gastric carcinogenesis (Hudler et al., 2004; Mitani et al., 2005; Schneider et al., 2010; Suzuki et al., 2006; Yamamoto et al., 2011).

In the 90's a model, describing genetic events of colorectal carcinogenesis, was suggested by Fearon and Vogelstein, which has shaped our understanding of the evolution of most types of malignancies today (Fearon \& Vogelstein, 1990). The so-called 'Vogelgram' predicts that alterations in at least four to five cancer-related genes (oncogenes and tumour suppressor 
genes) are needed for malignancy to occur, and that the total accumulation of changes rather than the order of their appearance is responsible for progression of the cancer (Fearon \& Vogelstein, 1990).

Although molecular mechanisms and alterations contributing to initiation and progression of gastric tumorigenesis are still not completely understood, it is now widely accepted that it is initiated by several genetic and epigenetic alterations that result in overexpression of oncogenes and growth factors, as well as impaired expression of tumour suppressor genes. It has also become evident that alterations in genome stability genes can initiate and accelerate these neoplastic processes (Nobili et al., 2011; Oda et al., 2005; Zheng et al., 2004). It is also important to note that the prevalence of these abnormalities varies between intestinal and diffuse types of gastric cancer (Hamilton \& Meltzer, 2006).

Recently, another type of genetic instability has been recognized as the most common feature of gastric cancers, namely chromosomal instability (CIN), leading to aneuploidy (Buffart et al., 2011; Nobili et al., 2011). New advances in high-throughput methodologies have shown that majority of solid tumours are characterized by gross chromosomal abnormalities, such as gain and/or loss of whole chromosomes or chromosomal segments (Duesberg \& Rasnick, 2000; Gollin, 2005).

\subsection{Oncogenes}

Cell proliferation is tightly regulated through signal transduction pathways, which are regulated by growth factors and their receptors. Alterations in growth factors and other oncogenes result in constantly active genes or active under conditions in which the wildtype genes are not. Oncogenes are mainly activated due to gene amplifications, intragenic mutations that regulate the activity of gene product or chromosomal translocations, all leading to overexpression of the oncoproteins. The occurrence and development of gastric cancer was found closely related to a variety of oncogenes, few of which are briefly discussed below.

Ras family oncogenes play an important role in the pathogenesis of colon and pancreatic cancers and were reported, though less frequently, in gastric carcinomas (Pellegata et al., 1992; Soh et al., 1993). The prevalence of alterations in HRAS (K-ras), which encodes a protein involved in cellular signal transduction pathways, appeared to be dependent of geographic and ethnic origins of gastric cancer cases. While HRAS mutations were rare in Western Europe and Japan, the prevalence in China was up to 30\% (Deng et al., 1994; Hiyama et al., 2002; van Rees et al., 1999). Genetic changes in HRAS have been observed in gastric intestinal metaplasia and gastric adenomas, and could be an early event in the development of gastric cancer (Hirohashi \& Sugimura, 1991; Osaki et al., 1996). Despite many studies focused on HRAS mutations, there is still some controversial data on the functional role of these mutations that needs to be elucidated.

Overexpression or activation, due to either amplification or mutation of genes of some tyrosine kinases (hepatocyte growth factor receptor (MET or c-met), fibroblast growth factor receptor 2 (FGFR2 or K-sam), human epithelial growth factor receptor 2 (HER2), and epithelial growth factor receptor (EGFR)) could be associated with human gastric cancer. Both, HER2 and EGFR, were found overexpressed in gastric cancer, with prevalence in the intestinal type cancers (Garcia et al., 2003). Receptors have an intracellular domain with tyrosine kinase activity and EGFR can bind ligands with its extracellular domain, which induces homodimerization of the receptor and generates autophosphorylation, initiating 
several signalling cascades that lead to DNA synthesis and cell proliferation. Overexpression of EGFR promotes cell migration, angiogenesis and inhibits apoptosis and has been observed in up to $47 \%$ of gastric cancers. Moreover, it was found to correlate with disease progression and poor clinical outcome (Malden et al., 1989; Yonemura et al., 1992; Yoshida et al., 1990). HER2 does not bind to any known ligand, but it is known to heterodimerize with other members of the family, especially when it is overexpressed. The protein has been reported to be overexpressed or activated in 19\% of gastric cancer cases. Studies suggest that overexpression of HER2 might be prognostic factor for intestinal-type gastric cancer associated with shorter relapse-free survival and overall survival (Vizoso et al., 2004; Zhang et al., 2009).

Abnormalities in genes, such as FGFR2 (K-sam), belonging to fibroblast growth factor receptor family, are associated with diffuse-type gastric cancer. Activation of FGFR2 has been found in approximately $50 \%$ of diffuse type gastric cancers, and was associated with neoplastic progression and metastasis (Hara et al., 1998; Hattori et al., 1996; Werner et al., 2001).

The oncogene MET (c-met) encodes a receptor with tyrosine-kinase activity that binds hepatocyte growth factor. Aberrantly active receptor was preferentially found in intestinaltype gastric cancer tumours and was correlated with poor prognosis (Nakajima et al., 1999; Tsugawa et al., 1998). Employing a simple method of fluorescent multiplex RT-PCR assay and capillary electrophoresis separation we found overexpression of $M E T$ in $56 \%$ of Slovenian patients with gastric cancer (Rajcevic et al., 2007; Rajcevic et al., 2001). MET amplification could constitute an important biomarker for selecting patients for a targeted therapy, because it has been observed that a fraction of gastric cancer cell lines appeared to be exquisitely sensitive to a specific MET inhibitor (Smolen et al., 2006).

Vascular endothelial growth factor (VEGF), a pro-angiogenic molecule, was found frequently overexpressed in poorly differentiated gastric cancer (Brown et al., 1993; Scartozzi et al., 2004; Tian et al., 2001; Yamamoto et al., 1998). Recently, a VEGF +1612G/A gene polymorphism was found to be associated with gastric cancer in Chinese Han patients and was previously shown to affect VEGF plasma levels (Zhou et al., 2011). Several other oncogenes have been found overexpressed in gastric carcinomas (Nobili et al., 2011; Rajcevic et al., 2007; Tahara, 2004). Nevertheless, years of research have shown that overexpression of oncogenes is not the sole mechanism implicated in gastric cancer pathogenesis.

\subsection{Suppressor phenotype}

Tumour suppressor genes are targeted in the opposite way than oncogenes. Molecular abnormalities that result in a truncation of the proteins, deletions or insertions or epigenetic silencing, reduce the activity of the gene product. Generally, alterations in both alleles are required to confer impairment of the gene product, except in the case of haplo-insufficient genes (Dang et al., 2008; Vogelstein \& Kinzler, 2004). Inactivation of the wild-type allele arises due to allelic loss, termed also loss of heterozygosity (LOH) or mutations (Knudson, 1993). The suppressor phenotype in gastric cancer is characterized by inactivation of suppressor genes, such as TP53 (p53), APC, MCC, DCC, CDH1, Rb1, FHIT, and other (Hamilton \& Meltzer, 2006; Nobili et al., 2011).

In our study we evaluated $\mathrm{LOH}$ on loci associated with the following tumour suppressors: TPp53, APC, nm23, and RB) and found that $52 \%$ of all cases exhibited $\mathrm{LOH}$ in at least one locus (Gazvoda et al., 2007). The highest frequency of LOH was at APC locus $(36 \%)$, 
followed by TP53-1 (33\%), nm23 (33\%), TP53-2 (24\%) and RB (24\%). Interestingly, $5 \%$ of the samples exhibited MSI on all the evaluated loci (in LOH as well as in MSI evaluation). These samples were associated with clinicopathological features that differed from the rest. All tumours belonged to intestinal type, displayed expansive growth and were mostly tubular. Furthermore, we found that LOH on loci TP53-1 and TP53-2 was associated with more expansive growth and LOH on TP53-1 locus tended to be associated with intestinal type tumours. In contrast, tumours without LOH on TP53-1 locus were associated with ulcerating, infiltrating type of gastric adenocarcinoma (Gazvoda et al., 2007).

The TP53 gene encodes a main regulator of cell growth and division, and its function in intestinal type of gastric cancer is mainly altered due to $\mathrm{LOH}$ and mutations. When protein p53 is impaired, the cells may not be able to induce apoptosis and control tumour growth (Vousden \& Prives, 2005). Studies showed that mutations in TP53 are present in a range of $40 \%-70 \%$ of early and advanced gastric cancers, and inactivation of TP53 resulting from $\mathrm{LOH}$ is found in $60 \%-70 \%$ of intestinal-type gastric cancers, thus making this gene among the most frequently mutated genes in cancers (Hamilton \& Meltzer, 2006; Werner et al., 2001). It was suggested that accumulation of mutations in TP53 is involved in initiating carcinogenic processes, though not all studies are in agreement with this hypothesis (Liu et al., 2001; Zwick et al., 1997). The expression of p53 protein can be easily detected by immunohistochemical staining, because mutations in TP53 gene increase the half-life of its product, and it was postulated that it could be used as a biomarker in a clinical setting (Zheng et al., 2004). However, there are conflicting results regarding the prevalence and of TP53 mutations and its expression and their relationship to clinicopathological features of gastric cancer (Panani, 2008). We and some other researchers found that the TP53 mutational status was not in association with p53 expression (Bataille et al., 2003; Juvan et al., 2007; Panani, 2008). Furthermore, we found that positive TP53 expression was associated with poorer survival, which was accordance with some other studies (Bani-Hani et al., 2005; Lazar et al., 2010). On the other hand, other studies did not reveal this association, therefore, the prognostic value of TP53 remains controversial (Panani, 2008).

Loss of APC gene function was first identified in $60 \%-80 \%$ of patients with familial adenomatous polyposis-associated colorectal cancers (Kinzler et al., 1991; Lynch \& Lynch, 1998). Mutations and $\mathrm{LOH}$ of the gene were also reported in more than $50 \%$ of gastric cancers of intestinal type (Tahara, 1995; Wright \& Williams, 1993). Functional product of APC gene targets $\beta$-catenin for ubiquitination, and thus prevents $\beta$-catenin associated induction of genes involved in growth control (Caca et al., 1999; Park et al., 1999).

E-cadherin, encoded by CDH1 gene, is an adhesion molecule expressed from epithelial cells, which plays a crucial role in epithelial structural integrity and was found to be implicated in carcinogenesis. Germline mutations in $C D H 1$ were first described in patients with hereditary diffuse type gastric cancer, however the rate of $C D H 1$ mutations in sporadic gastric cancer was found to be as high as $50 \%$, and reduced expression of E-cadherin protein was found in 51\% of diffuse type gastric cancers (Becker et al., 1994; Guilford et al., 1998; Xiangming et al., 1999). Susceptible individuals with a germline mutation in tumour suppressor gene $C D H 1$ require the inactivation of the second allele due to somatic mutation or DNA methylation, rendering E-cadherin completely inactive (Becker et al., 2000). Abnormal expression of E-cadherin is thought to promote metastatic ability of gastric cancer cells (Kanai \& Hirohashi, 1997). 


\subsection{Alterations in other genes}

Genetic and epigenetic abnormalities have been found in numerous other genes that participate in proliferation, invasion and metastasis, such as cell cycle regulators, celladhesion molecules, growth factors, cytokines, nuclear factors, matrix metalloproteinases, DNA repair genes, and apoptosis regulators (Nobili et al., 2011; Tahara, 2004; Yokozaki et al., 2001). For example, cyclin E1 together with cyclin-dependent kinase, CDK2, promotes the entry into the S-phase of the cell cycle, and it was found overexpressed in one third of gastric cancer cases. Amplification of this gene was found to correlate with tumour aggressiveness (Jiaqing et al., 1998; Nobili et al., 2011; Xiangming et al., 2000). In our study we observed overexpression of cyclin E1 in $42 \%$ of patients with gastric cancer and in $57 \%$ of patients with precancerous lesions, indicating that abnormalities in this gene could be early event in gastric carcinogenesis (Rajcevic et al., 2007). Moreover, we also found overexpression of epidermal growth factor family members, such as TDGF1 and EGF, and NRG1, signalling protein, that mediates cell-cell interactions and plays critical roles in the growth and development of multiple organ systems (Rajcevic et al., 2007). Several other genes have been reviewed extensively elsewhere (Nobili et al., 2011; Resende et al., 2010; Tahara, 2004; Wu et al., 2010; Yokozaki et al., 2001).

\subsection{MSI and mutator phenotype}

Molecular abnormalities in oncogenes and tumour suppressor genes drive the neoplastic process by increasing tumour growth. The increase is achieved by activating of genes that drive the cell cycle or by inhibiting normal apoptotic pathways (Vogelstein \& Kinzler, 2004). The third class of genes that contribute to cancer development are the stability genes, which, when mutated, promote tumorigenesis in a completely different way. They keep genetic alterations to a minimum, and thus, when they are inactivated, mutations in oncogenes and tumour suppressor genes occur at a higher rate (Freiberg, 2003). As with tumour suppressor genes, both alleles must be inactivated for physiologic effect to result.

Mismatch repair (MMR) genes are an example of genome stability genes and molecular inactivation of these genes is a hallmark of so-called mutator pathway, which results in microsatellite instability (MSI) or mutator phenotype. Microsatellites are short tandem repeats abundant throughout the genome. They are polymorphic among individuals, but their length is stable in every noncancerous tissue within a given individual. Patients with MSI phenotype exhibit a high frequency of changes in length of microsatellites within a tumour tissue compared to normal tissue, due to slippage of DNA polymerase during DNA replication on repetitive sequences, which leads to insertion or deletion of nucleotides. In short, MSI phenotype is characterized by appearance of new alleles not present in the normal genotype. These postreplicational DNA errors are detected and repaired by a complex of MMR proteins, rather than proofreading activity of the polymerase. Inactivation or deficiency of one or more MMR genes, particularly MLH1 or MSH2, leads to manifestation of MSI phenotype in gastric cancer. As shown in Figure 1, MSI often leads to additional genetic changes and allelic losses, due to frameshift mutations in coding repetitive sequences of genes involved in cell growth regulation, apoptosis and DNA repair (Buermeyer et al., 1999; Ottini et al., 2004). Remarkably, every human MMR gene except MLH1 includes a mononucleotide repeats, suggesting that the MMR process becomes increasingly defective with subsequent losses of involved proteins (Perucho, 1996). 
Impairment of MMR, eventually leading to cancer development, can occur: 1) by mutational inactivation of one or two MMR genes, or 2) by epigenetic inactivation of MMR genes. In gastric cancer, functional inactivation of MMR is mainly caused by latter. Epigenetic hypermethylation of MLH1promoter has been found to be responsible for the development of the majority, more than $50 \%$, of MSI-H positive gastric cancers, whereas mutations in MLH1 and MSH2 are being reported in 12-15\% of gastric cancer exhibiting MSI-H phenotype (Bacani et al., 2005; Wu et al., 2000; Yamamoto et al., 1999) (Figure 1). Silencing of multiple genes, including known tumour-related genes such as CDKN2A (p16), hMLH1, THBS1, and CDH1, due to promoter hypermethylation, is an important epigenetic event in stomach carcinogenesis and was shown to occur in early stages of gastric cancer development. This pathway of methylation of $\mathrm{CpG}$ islands characterizes alternative molecular phenotype of gastric cancer, referred to as the CpG island methylator phenotype (CIMP) (Nobili et al., 2011; Oue et al., 2001; Resende et al., 2010).

\subsubsection{MSI analysis}

MSI can be detected with polymerase chain reaction (PCR), where each microsatellite under investigation is amplified using specific primers. Lengths of PCR obtained products are usually assessed and compared between normal and tumour tissues from each individual using a simple and cost effective fluorescent multiplex PCR, followed by capillary electrophoresis separation (Gazvoda et al., 2007; Suraweera et al., 2002). Because of a huge number and diversity of microsatellite regions in the human genome, it is difficult to determine the prevalence of MSI in human cancers and its incidence varies depending on which loci are investigated (Lawes et al., 2003). To overcome this confusion, a standard panel of microsatellite markers, including mononucleotide repeats (BAT25 and BAT26) and dinucleotide repeats (D2S123, D5S346 and D17S250) has been recommended to identify MSI phenotype (Nobili et al., 2011). Cancers were subdivided in three groups based on the number of markers displaying instability: those demonstrating instability in $>30-40 \%$ of the loci investigated were classified as high-level MSI (MSI-H); those demonstrating instability in $<30-40 \%$ of the loci investigated were classified as low level MSI (MSI-L); and stable cancers (MSS) showing no instability (Boland et al., 1998). Although these criteria were initially aimed at identifying MSI positive colorectal cancer, they were also successfully used for detecting MSI-H gastric cancers. Incidence of MSI-H has been observed in range 2-18\% of gastric cancer cases, depending on the ethnic background. In Japan the incidence of MSI$\mathrm{H}$ phenotype in patients with gastric cancer was reported in $5 \%$ of cases, whereas in Western populations it was ranging from 2 to 15\% (Gu et al., 2009; Hudler et al., 2004; Leung et al., 1999; Pedrazzani et al., 2009; Schneider et al., 2000; Zhou et al., 1998). Moreover, studies reported 3-fold higher prevalence of MSI-H status in intestinal rather than diffusetype gastric cancers (Leite et al., 2011). As reviewed by Lawes et al., patients with gastric cancer that exhibit MSI-H phenotype were associated with a better survival (64-88\%) when compared to MSS counterparts (39-53\%) (Lawes et al., 2003). Furthermore, we and other researchers have found that MSI-H phenotype was not associated with LOH-H phenotype, which is in agreement with other studies proposing that the mutator and suppressor pathways are independent of each other at least in the early stages of gastric carcinogenesis (Gazvoda et al., 2007; Kim et al., 2001). Likewise, patients with LOH-H were associated with MSI-L or did not show MSI (microsatellite stable, MSS) on evaluated loci. In our study we 
evaluated MSI on loci BAT25, BAT26, BAT40, D2S123, D3S1277, and D10S107, and as mentioned before, $\mathrm{LOH}$ on loci, associated with tumour suppressors. Interestingly, the highest frequency of MSI was found at RB locus (21\%), which was initially tested for LOH, followed by BAT25 (15\%), D3S1277 (14\%), D2S123 (13\%), D10S107 (13\%), BAT40 (12\%) and BAT26 (10\%) (Gazvoda et al., 2007). We observed that in our study BAT26 was the most informative locus. We also correlated MSI with clinicopathological features and found that MSI-L phenotype was associated with diffuse or mixed types of gastric cancers.

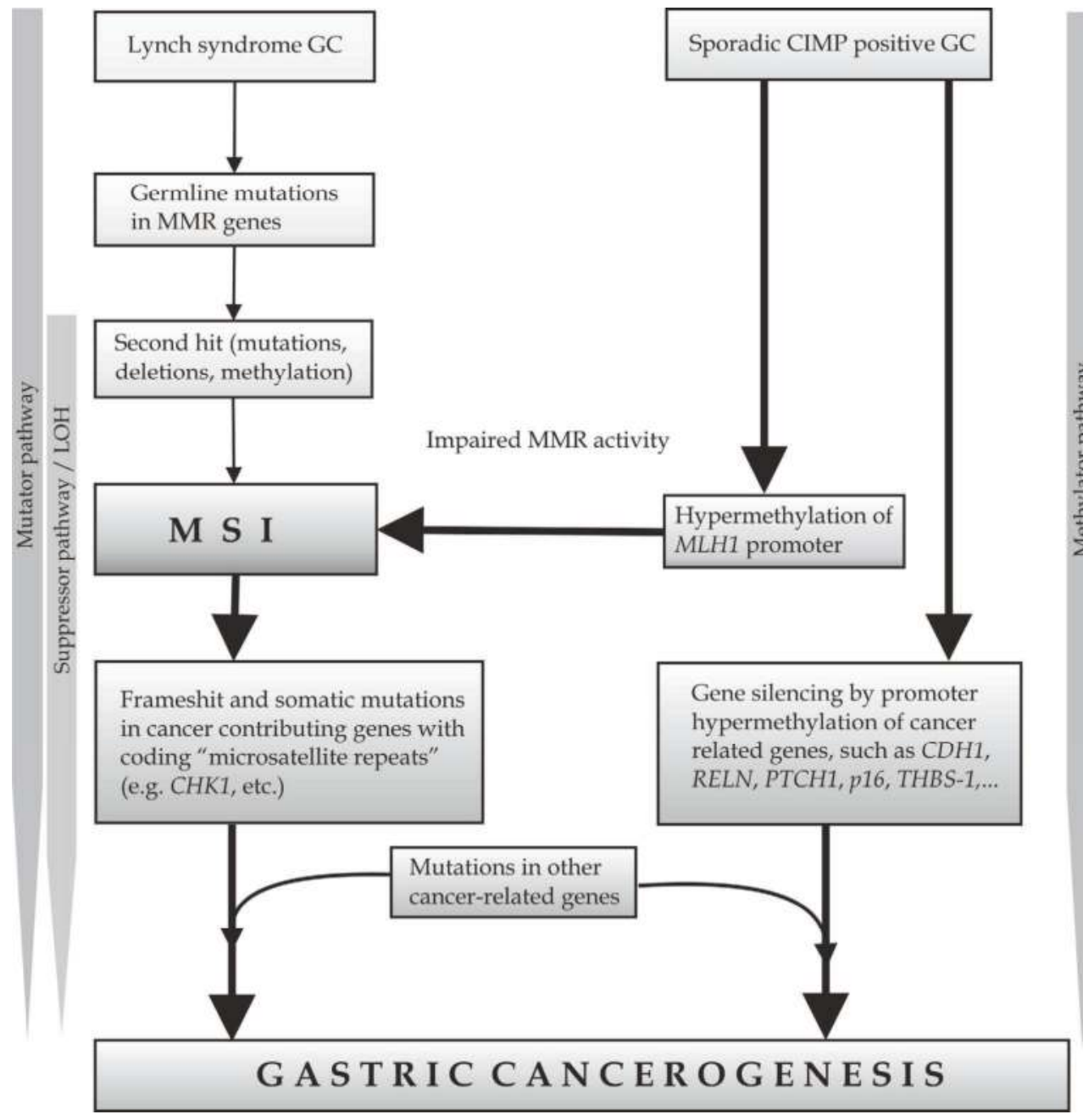

Fig. 1. Mutator pathway overlapping with suppressor and methylator pathways in gastric tumorigenesis. These changes should not be considered a specific sequence of alterations, but rather an overall collection of abnormalities that contribute to the pathogenesis of gastric cancer (Adopted from Boland \& Goel, 2010). 
It has recently become evident that dinucleotide repeats are less sensitive than mononucleotide repeats for detection of MSI-H, therefore revised criteria proposes the use of a mononucleotide markers in order to define MSI-H instability (Umar et al., 2004). A panel of five mononucleotide repeats (BAT25, BAT26, NR-21, NR-22 and NR-24) that may be more instrumental for detecting MSI-H status in humans has been suggested (Buhard et al., 2004). It has been further demonstrated that these markers are quasimonomorphic in 1206 studied individuals from 55 different populations worldwide, and can therefore be used for MSI-H determination without the requirement for matching normal DNA (Buhard et al., 2006). By adopting the panel, MSI-H phenotype was reported in a range from $5 \%$ to $50 \%$ of all gastric carcinomas with significant differences in various population groups (Leite et al., 2011; Ottini et al., 2004; Simpson et al., 2001).

\subsubsection{Mutational impairment of MMR activity and pathogenic significance of observed alterations}

The most common inherited condition that gives rise to MSI positive cancers is Lynch syndrome, an autosomal dominant disease, also referred to as Hereditary Non-polyposis Colorectal Cancer (HNPCC), where gastric cancer is a common neoplasia, occurring in $6 \%$ of Lynch syndrome cases (Percesepe et al., 2001; Samowitz et al., 2001). Predisposed individuals carry a recessive, first-hit germline mutation in the MMR genes, including large genomic rearrangement, which account for $5-20 \%$ of all mutations. In reference of Knudson's hypothesis, the MSI-H phenotype requires the "second hit" inactivation of the responsible MMR gene for development of malignant phenotype.

In Lynch syndromes, somatic inactivation of the remaining wild-type allele can occur due to different mechanisms: loss of heterozygosity $(\mathrm{LOH})$, somatic mutation and promoter methylation (Imai \& Yamamoto, 2008). The relative risk of gastric cancer development in Lynch syndrome individuals has been reported to be 4-19-fold higher, compared to general population, suggesting that screening for MMR mutations in predisposed carriers could be of importance for the detection of predisposed individuals (Gylling et al., 2007). Particularly, patients with MSI-positive gastric carcinomas, but lacking MLH1 promoter hypermethylation are regarded as potential germline MMR-related mutation carriers.

Majority of MMR alterations, found in patients with Lynch syndrome are known to be pathogenic as they result in premature termination of protein synthesis and thus loss of MMR activity. However, hundreds of MMR variants that do not lead to truncation of the respective MMR protein have been identified in Lynch cancer cases and their pathogenic significance is often difficult to establish on clinical samples alone.

Information on functional nature of MMR alterations is essential for accurate early diagnosis and prognosis as well as for proper genetic counselling for members from affected families. Therefore in the past decade, many functional assays have been developed to ease the interpretation of pathogenicity of unclassified variants (UVs). Recent and some of the most recognized in vivo and in vitro assays together with available in silico algorithms are summarised in Table 1.

While many in vitro assays characterize specific biological functions of MMR proteins, in vivo tests strive to assess the MMR repair capacity as a complex cellular process (Ou et al., 2007). Since efficiency of MMR repair relies on several successfully completed biochemical events of involved proteins (e.g. protein expression levels and stability, localization of MMR protein to the nucleus, heterodimerization ability and effective recognition and repair of the DNA lesions, etc.), in vivo approaches are preferable and are either cell line- or yeast-based. However, all assays have their limitations and problems, mostly concerning toxic episomal overexpression of MMR proteins and lack of evolutionary conserved regions between yeast 
and human MMR proteins at the regions of interest. Moreover, since variety of strategies have been used, it is difficult to establish and compare clinical significance of analysed variants. Finally, it is also not easy to determine sensitivity and specificity of these tests, therefore results should still be utilized with caution and interpreted alongside clinical data of the affected carriers.

\begin{tabular}{|c|c|c|c|}
\hline $\begin{array}{l}\text { Assay } \\
\text { type }\end{array}$ & $\begin{array}{c}\text { Biochemical } \\
\text { feature analysed }\end{array}$ & Assay & References \\
\hline \multirow[t]{5}{*}{ In vitro } & \multirow[t]{2}{*}{$\begin{array}{l}\text { Protein-protein } \\
\text { interaction }\end{array}$} & GST pull-down & $\begin{array}{c}\text { Raevaara, 2005; Guerette, } \\
\text { 1999; } \\
\text { Belvederesi, 2006; Perera, } \\
2008\end{array}$ \\
\hline & & $\begin{array}{c}\text { Expression of MMR genes in } \\
\text { human cell lines }\end{array}$ & Trojan, 2002 \\
\hline & $\begin{array}{c}\text { Protein } \\
\text { expression }\end{array}$ & Western blotting & Takahashi, 2007 \\
\hline & mRNA splicing & pCAS minigene & Tournier, 2008 \\
\hline & MMR activity & $\begin{array}{l}\text { Cell-free assay w/ protein } \\
\text { extracts }\end{array}$ & $\begin{array}{c}\text { Takahashi, 2007; Raevaara, } \\
\text { 2005; }\end{array}$ \\
\hline \multirow[t]{8}{*}{ In vivo } & $\begin{array}{c}\text { Protein-protein } \\
\text { interaction }\end{array}$ & $\begin{array}{c}\text { Human-yeast hybrid MLH1 in } \\
\text { yeast }\end{array}$ & Kondo, 2003; \\
\hline & $\begin{array}{c}\text { Protein } \\
\text { expression }\end{array}$ & Immunohistochemical staining & Leite, 2011 \\
\hline & $\begin{array}{l}\text { Intracellular } \\
\text { localization }\end{array}$ & Fluorescence microscopy & Raevaara, 2005 \\
\hline & mRNA splicing & $\begin{array}{l}\text { In vivo splicing assay in human } \\
\text { cells }\end{array}$ & $\begin{array}{c}\text { Auclair, 2006; Sharp, 2004; } \\
\text { Arnold, } 2009\end{array}$ \\
\hline & \multirow[t]{4}{*}{ MMR activity } & $\begin{array}{l}\text { Yeast-based chromosome- } \\
\text { integrated hMMR gene }\end{array}$ & $\begin{array}{l}\text { Vogelsang, 2009; } \\
\text { Vogelsang, 2010 }\end{array}$ \\
\hline & & Dominant mutator effect & $\begin{array}{c}\text { Raevara, 2005;Takahashi, } \\
\text { 2007; Shimodaira, } 1998\end{array}$ \\
\hline & & Functional assay using yeast & Ellison, 2001;Wanat, 2007 \\
\hline & & Utility of $M L H 1$-deficient cells & Blasi, 2006 \\
\hline \multirow[t]{5}{*}{ In silico } & \multirow{4}{*}{$\begin{array}{c}\text { Effect of amino } \\
\text { acid substitution } \\
\text { on protein } \\
\text { functions }\end{array}$} & SIFT & Kumar, 2009; Ng, 2003 \\
\hline & & PolyPhen & Ramensky, 2002 \\
\hline & & MAPP-MMR & Chao, 2008 \\
\hline & & Align GVDV & $\begin{array}{l}\text { Tavgtigian, 2006; Mathe, } \\
2006\end{array}$ \\
\hline & mRNA splicing & NNSPLICE & Sharp, 2004 \\
\hline
\end{tabular}

Table 1. Compilation of functional assays used in characterizing pathogenic significance of MMR variants found in Lynch syndrome patients.

We have recently described an in vivo yeast-based functional approach, expressing human MMR genes in yeast, enabling all variants found within the coding region of the MMR gene to be analysed. With chromosomal integration of relevant human MMR genes we obtained their stable expression throughout the experiment (Vogelsang et al., 2009). With our 
approach we have functionally characterized four missense MLH1 variants, which we previously identified in MSI-H positive gastric cancers with limited MLH1 hypermethylation. We also assessed two of the variants, which were described for the first time in our study (Hudler et al., 2004). We have shown that identified missense mutations were not causally associated with MSI-H phenotype in analysed gastric cancer tissues (Vogelsang \& Komel, 2010).

\subsection{Chromosomal instability (CIN) and aneuploidy}

In contrast to MSI, CIN is characterized by gross chromosomal abnormalities, such as gain or loss of whole chromosomes and/or fractions of chromosomes ( $\mathrm{LOH}$, amplifications, translocations) (Martin et al., 2010). Aneuploidy is the state of altered chromosome number in malignant cells (Pino \& Chung, 2010). Studies showed that MSI phenotype is characteristic for hereditary type of gastric cancer, developed in the context of Lynch syndrome, and a smaller subset of sporadic cancers ranging from 15\% to 35\% (Panani, 2008). CIN, however, has been recently recognized as the most common feature of sporadic gastric cancers, and has been reported in up to $84 \%$ of gastrointestinal tumours (Grabsch et al., 2004; Ottini et al., 2006).

Several techniques, such as karyotyping, cytometry, detection of $\mathrm{LOH}$, and fluorescent in situ hybridization (FISH) have been developed to measure CIN and some of them have already been successfully transferred to clinical practice. New methods, such as CGH arrays and copy number variation analysis (CNV), have advanced the field, due to their ability to detect chromosomal abnormalities with higher resolution and accuracy (Pino \& Chung, 2010).

CIN has been recognized as valuable prognostic factor and tumour stage indicator in gastric cancers, although in the study of Birkbak et al. it has been found that intermediate CIN had more impact on poor prognosis than extreme CIN phenotype (Birkbak et al., 2011; Suzuki et al., 2003). Furthermore, it has been found that DNA copy number changes are not uniform in gastric cancers and subgroups with different patterns of DNA copy number alterations have been recognized, which have been associated with prognosis, lymph node status and metastasis (Buffart et al., 2007b; Kang et al., 2006; Morohara et al., 2005; Panani, 2008; Weiss et al., 2004; Wu et al., 2002).

Buffart et al. explored the differences in DNA copy number by CGH arrays and reported that the mean number of chromosomal events was lower in adenomas compared to gastric carcinomas, suggesting that distinct losses and gains on chromosomes likely represent early events in carcinogenesis (Buffart et al., 2007b). In another study they compared CGH profiles of gastric cancers in young and old patients (Buffart et al., 2007a). They found out that chromosome regions 11q23.3 and 19p13.3 contributed most to age-related differences in tumour profiles and that tumours of younger patients showed gains in chromosomal regions $6 \mathrm{p} 21,9 \mathrm{p} 34,11 \mathrm{p} 15,11 \mathrm{q} 23,17 \mathrm{p} 13,19 \mathrm{p} 13$, and 22q13, whereas in the majority of older patients normal copy status was observed. They concluded that these differences in genomic profiles likely reflect different pathogenic mechanisms of the disease.

Varis et al., similarly observed that the most frequent cytogenetic aberrations were gains seen at 17q, 19q, and 20q in younger patients (Varis et al., 2003). They also found that DNA copy number changes were mostly detected in intestinal or mixed types of tumours. 
Tsukamoto et al. observed higher frequencies of DNA copy number aberrations, especially in the case of $20 \mathrm{q} 13$ chromosome gain, which was detected in $97 \%$ of cases, compared to other studies (Tsukamoto et al., 2008). They used laser microdissection method to isolate tumour cells, therefore their samples contained fewer cells from tumour microenvironment. They also identified 114 upregulated candidate genes located in regions of amplification and 11 down-regulated genes located in regions of deletion.

Several other studies reported different DNA copy number changes in patients with gastric cancer (Buffart et al., 2007b; Hou et al., 2008; Junnila et al., 2010; Kimura et al., 2004). Hou et al., for example, used an integrated approach using CGH and 100K SNP arrays, FISH, reverse transcription PCR, Western immunoblotting, and siRNA-mediated gene knockdown to determine and identify potential overexpressed genes in region $6 \mathrm{p} 11 \mathrm{p} 12$, which they found to be amplified in their study (Hou et al., 2008). They identified RAB23, which could be implicated in invasion.

Despite the remarkable effort made by researchers to identify significant chromosomal aberrations in gastric cancers and to correlate them with clinicopathological features, the results are still inconclusive and not consistent with each other (reviewed in Nobili et al., 2011; Panani, 2008).

\subsubsection{LOH}

As stated before, LOH studies have already revealed several chromosomal loci with significant allelic losses, facilitating the identification of tumour suppressor genes, which could be important in gastric tumorigenesis (Gazvoda et al., 2007; Juvan et al., 2007; Kim et al., 1991; Kondo et al., 2005; Panani, 2008; Tamura, 2006). LOH is also a marker of chromosomal instability and might indicate a second inactivational hit of a cancer suppressor gene. Allelic losses are typically detected by using highly polymorphic microsatellite sequences that are dispersed throughout the human genome. Several LOH studies demonstrated that the extent of chromosomal loss appeared to be of prognostic significance (French et al., 2004; Gazvoda et al., 2007; Koo et al., 2004). It was established that there was a trend of two distinct subtypes, high-level $\mathrm{LOH}$ (named $\mathrm{LOH}-\mathrm{H}$ ) and low-level $\mathrm{LOH}$ (named LOH-L), being correlated with intestinal or mixed and diffuse growth patterns, respectively (Hong et al., 2010). In our study we also found out that LOH-H was associated with intestinal type of gastric cancer (Gazvoda et al., 2007). LOH has been shown to relate to cancer progression, where a transition from $\mathrm{LOH}-\mathrm{L}$ to $\mathrm{LOH}-\mathrm{H}$ is thought to reflect an increase in chromosomal instability during tumour advancement. These findings on $\mathrm{LOH}$ events suggest that the degrees of allelic loss may have an influence on the clinical course of gastric cancer.

\subsubsection{Aneuploidy}

Although some opinions still diverge regarding the clinical impact of aneuploidy alone (mostly measured by FISH, flow cytometry or image cytometry), recently there are reports pointing out that it could be of importance as a predictive marker in gastric cancer, and its potential clinical practicability in pre-malignant disease to stratify patients by their cancer risk. It is important to note recent evidence supporting the hypothesis of stepwise ploidy progression: from diploid or minor aneuploid in most early cancers to aneuploid in most advanced cancers (Duesberg et al., 2005). As a progressive increase in the severity of aneuploidy with neoplastic progression has been observed, it has thus been shown to be a 
useful prognostic indicator for patient classification as low or high-risk cases for cancer development (Russo et al., 2000; Yasa et al., 2005).

Interestingly, aneuploidy was found in human tumours more than 100 years ago by von Hansenmann and Boveri (Duesberg \& Rasnick, 2000; Ricke et al., 2008). However, in the last decades, the research was oriented towards oncogenes and tumour suppressors' hunt, and in identifying mutator and methylator pathways of gastric carcinogenesis. Yet to date, not one subtype of gastric adenocarcinomas has been completely described and no cancercausing genes or combination of genes have been found to be specific for gastric cancers, although a number of mutations and other genetic changes have been described (Duesberg \& Rasnick, 2000; Nobili et al., 2011; Panani, 2008; Weber, 2002).

Recently, it has been found that aneuploidy, either in the form of $\mathrm{LOH}$ or gross chromosomal copy number changes, stands out as the most consistent marker of neoplastic cells in solid tumours (Duesberg \& Li, 2003; Ottini et al., 2006). Indeed, several studies confirmed a high frequency of aneuploidy in sporadic gastric cancers, even up to $84 \%$ (Belien et al., 2009; Buffart et al., 2007b; Buffart et al., 2011; Grabsch et al., 2004; Russo et al., 2000).

\subsubsection{Mechanisms leading to chromosomal instability}

The mechanisms leading to abnormal chromosome content and other chromosomal abnormalities are poorly understood, although it is now believed that CIN might, through stepwise clonal progression, lead to oncogene activation, tumour suppressor inactivation and alterations in other crucial genes, implicated in establishing the malignant phenotype of cells. Several different mechanisms have been proposed by researchers, such as telomere dysfunction, defective DNA damage response, impaired chromosomal segregation, and aberrations in cell cycle regulators (Castro et al., 2007; Gollin, 2005; Grabsch et al., 2004; Yasui et al., 1999).

Lately, the attention of researchers in the field of epithelial tumours, including gastric adenocarcinomas, has focused on genetic changes in mitotic genes, with emphasis on chromosome segregation. Segregation is one of the fundamental processes in cells, which are rapidly dividing, such as gastric epithelial cells. Therefore, if regulation mechanisms, governing this process are damaged, the cells might proceed through cytokinesis with DNA or spindle errors and thus could inherit unrepaired mutations or gain an abnormal number of chromosomes (aneuploidy) (Schmit \& Ahmad, 2007). However, the molecular defects underlying CIN and aneuploidy and weather it is a cause or consequence of tumour phenotype are not completely clear. At least two possible mechanisms for CIN development have been suggested: mutations and/or polymorphisms in mitotic genes, implicated in chromosome segregation, or the activity of carcinogens on susceptible genetic background of individuals. (Duesberg et al., 2005; Iovino et al., 2006).

Studies on several animal species and humans showed that certain genetic mutations and polymorphisms in genes involved in segregation of chromosomes might cause an increased incidence of a particular tumour type (Shepard et al., 2007; Tomonaga \& Nomura, 2007). Kim et al. analysed expression of MAD2L1, a component of the mitotic spindle assembly checkpoint, and kinase gene BUB1, involved in activating the spindle checkpoint. They found mutations in MAD2L, whereas they did not detect any mutations in BUB1.

Grabsch et al., on other hand, observed overexpression of BUB1 protein in gastric cancers, which was significantly higher in tissues of patients with diffuse type adenocarcinomas 
(Grabsch et al., 2004). However, their study did not reveal any association between BUB1 protein expression level and DNA ploidy status of examined tumour types.

Aurora kinase A (AURKA or STK15) located at 20q13, a region that is frequently amplified in gastric cancer, has been found overexpressed in stomach adenocarcinomas (Dar et al., 2008). Functional analysis of upregulated AURKA gene, done by the same researchers, revealed a possible novel oncogenic pathway, involved in gastric carcinogenesis. AURKA overexpression led to a significant increase in mRNA levels of several direct targets of the $\beta$ catenin/TCF transcription complex (cyclin D1, MYC, MYC-binding protein, CLDN1, FGF18, and $V E G F)$.

However, these and several other studies, explored overexpression and/or mutations of these genes, which could already be the consequence of CIN. Therefore, it has been proposed that minor alterations in mitotic genes could contribute to the onset of cancer (Frank, 2004). The mounting evidence is suggesting that subtle variations, such as singlenucleotide polymorphisms (SNPs) or non-lethal mutations, might induce CIN and aneuploidy. This hypothesis of low-penetrance allelic variants or risk alleles is further supported by the fact that non-heritable cancers usually develop in elderly, whereas dominant mutations in oncogenes and tumour suppressors usually induce the disease early in life (Duesberg \& Rasnick, 2000; Frank, 2004). Minor genetic variants in mitotic genes could in combination with environmental factors modulate mitotic pathways, and could thus exert minor changes in the DNA of replicating epithelial cells. The search for these changes has begun only recently, and further investigations are needed to clarify these aberrations and their involvement in carcinogenesis.

In our study, we genotyped two polymorphic sites, T91A (F31I) and G169A (V57I) in serinethreonine-kinase STK15 (AURKA), which is involved in the regulation of several cell cycle events (Hudler et al., 2009). It is responsible for the functioning of centrosome, for microtubule formation and stabilization at the spindle pole throughout all phases of segregation, and for chromosome segregation during anaphase. We found a putative protective role of the genotype A/T (F31I) in examined population of gastric cancer patients. We also found a weak protective association between homozygotes $\mathrm{A} / \mathrm{A}$, heterozygotes A/G (V57I) and A/T (F31I) genotype and reduced risk for perineural invasion. In another study we performed the case-control study of selected polymorphisms rs151658 and rs239559, rs1031963 and rs1801376 in mitotic segregation genes, TTK and BUB1B, respectively (Hudler et al., 2010). We found a significant interaction between patients and control cases for genotype A/G in rs151658 polymorphism. We also observed a statistically important difference in genotype frequencies between female patients and control cases for polymorphism rs1801376. Our results showed that this difference was significant only for female population of patients. Polymorphisms rs151658, rs1031963 and rs1801376 showed significant associations with certain clinicopathological factors, such as differentiation of tumours, infiltration, and intestinal type of gastric cancers. This study provides new support for the role of mitotic genes in gastric cancer development, suggesting that smaller changes could be associated with genetically unstable gastric tumours. However, the biological basis for the role of risk alleles of mitotic genes in cancers of the upper gastrointestinal tract needs to be established to understand its consequences and role during carcinogenesis.

Carcinogens are a second probable cause of CIN and particular agents, such as Helicobacter pylori infection, tobacco, nitrates, and nitrites have an important impact on gastric tumorigenesis in genetically susceptible individuals (Matysiak-Budnik \& Megraud, 2006). In 
addition, a combination of SNPs within pro-inflammatory genes IL-1 $\beta$, IL-1RA, TNFa, and IL-10 conferred even greater risk for gastric cancer development in combination with CIN causing Helicobacter pylori infection (El-Omar et al., 2003).

\section{Future directions}

Recent advances in high-throughput methods revealed the lack of consistency regarding the number and species of genes mutated in all subtypes of gastric adenocarcinomas, or even from one cell to another within the same tumour, which points to amazing genetic diversity of cancer cells. The idea that mutations in a few specific genes are necessary and sufficient to cause the disease in any of the most common human cancer forms was opposed by observation that random mutations accumulate much faster inside genetically unstable malignant cells and that genome instability might be a critical early event that leads to the mutation of oncogenes and suppressor genes. Furthermore, in contrast to gene mutation hypotheses neoplastic transformation of normal epithelial cells is a slow process, which explains the fact that majority of cancers appear at an advanced age. All these facts make relevant molecular cancer diagnosis and treatment extremely complex and difficult to fulfil. Therefore, in the future we suggest performing combined analyses of gene expression profiles, genetic polymorphisms in mitotic genes, and functional analyses of these polymorphisms. Studies should be expanded on candidate genes by employing genomewide association studies in order to identify novel genetic variants associated with gastric cancer.

\section{Conclusion}

It is apparent that majority of gastric cancers are characterized by genetic instability, either MSI or CIN. Whereas MSI is characterized by changes in short repeat sequences, the hallmark of CIN are gross chromosomal rearrangements, such as the gain or loss of whole chromosomes (Martin et al., 2010). Accumulating evidence shows that CIN and aneuploidy are the most common characteristics of sporadic gastric adenocarcinomas, accounting for more than $60 \%$ of cases, whereas MSI is characteristic for hereditary type of gastric cancer, developed in the context of Lynch syndrome, and a smaller subset of sporadic cancers, ranging from $15 \%$ to $35 \%$ (Panani, 2008). The newly formed chromosomal/aneuploidy hypothesis (aneuploidy could be the consequence of carcinogens or genetic changes in certain mitotic genes) could answer several questions remaining from the currently established classic oncogene overexpression model, mutator and suppressor theories, which postulate that cancer is caused by clonal expansion of one single cell, which has accumulated 4-7 mutations during the lifetime of a patient. (Castro et al., 2007; Duesberg et al., 2005; Duesberg et al., 2000). However, these theories do not explain the long latent periods in cancer development and more importantly, despite more than two decades of effort, they have failed to identify a particular sets of gene mutations that occur in every instance of gastric tumour development.

It is evident that gastric cancer is the consequence of a multistep process involving different genetic and epigenetic changes in numerous genes. Host genetic background and environmental factors also play an important role in the pathogenesis of the disease. The majority of genetic alterations contributing to the malignant transformation were observed in growth regulatory genes, and in genes involved in cell cycle progression and arrest. 
However, exact genetic steps involved in the stomach carcinogenesis still remain uncertain. Different histological forms, as well as different aetiologies point to different genetic pathways for intestinal and diffuse tumours. To date, no single genomic abnormality is known to be specific to sporadic gastric cancer, or to any of its histological subtypes. Some of the genetic changes occur commonly in both major types, intestinal and diffuse, but some differ depending on the histological type. Even more, recent studies supported the idea that there are subgroups where MSI, CIN, suppressor, and methylator pathways overlap during the development of malignant phenotype. In conclusion, further research is required, with emphasis on collecting as many genetic changes as possible, which could aid in deciphering the molecular mechanisms of gastric cancer and in the development of suitable methods for screening, risk assessment and prognostic evaluation.

\section{References}

Arnold, S., Buchanan, D. D., Barker, M., Jaskowski, L., Walsh, M. D., Birney, G., Woods, M. O., Hopper, J. L., Jenkins, M. A., Brown, M. A., Tavtigian, S. V., Goldgar, D. E., Young, J. P. \& Spurdle, A. B. (2009). Classifying MLH1 and MSH2 variants using bioinformatic prediction, splicing assays, segregation, and tumor characteristics. Hum Mutat, 30, (5), pp. 757-770, ISSN 1098-1004

Auclair, J., Busine, M. P., Navarro, C., Ruano, E., Montmain, G., Desseigne, F., Saurin, J. C., Lasset, C., Bonadona, V., Giraud, S., Puisieux, A. \& Wang, Q. (2006). Systematic mRNA analysis for the effect of MLH1 and MSH2 missense and silent mutations on aberrant splicing. Hum Mutat, 27, (2), pp. 145-154, ISSN 1098-1004

Bacani, J., Zwingerman, R., Di Nicola, N., Spencer, S., Wegrynowski, T., Mitchell, K., Hay, K., Redston, M., Holowaty, E., Huntsman, D., Pollett, A., Riddell, R. \& Gallinger, S. (2005). Tumor microsatellite instability in early onset gastric cancer. J Mol Diagn, 7, (4), pp. $465-477$

Bani-Hani, K. E., Almasri, N. M., Khader, Y. S., Sheyab, F. M. \& Karam, H. N. (2005). Combined evaluation of expressions of cyclin E and p53 proteins as prognostic factors for patients with gastric cancer. Clin Cancer Res, 11, (4), pp. 1447-1453, ISSN 1078-0432

Bataille, F., Rummele, P., Dietmaier, W., Gaag, D., Klebl, F., Reichle, A., Wild, P., Hofstadter, F. \& Hartmann, A. (2003). Alterations in p53 predict response to preoperative high dose chemotherapy in patients with gastric cancer. Mol Pathol, 56, (5), pp. 286-292

Becker, K. F., Atkinson, M. J., Reich, U., Becker, I., Nekarda, H., Siewert, J. R. \& Hofler, H. (1994). E-cadherin gene mutations provide clues to diffuse type gastric carcinomas. Cancer Res, 54, (14), pp. 3845-3852, ISSN 0008-5472

Belvederesi, L., Bianchi, F., Loretelli, C., Gagliardini, D., Galizia, E., Bracci, R., Rosati, S., Bearzi, I., Viel, A., Cellerino, R. \& Porfiri, E. (2006). Assessing the pathogenicity of MLH1 missense mutations in patients with suspected hereditary nonpolyposis colorectal cancer: correlation with clinical, genetic and functional features. Eur J Hum Genet, 14, (7), pp. 853-859, ISSN 1018-4813

Becker, K. F., Keller, G. \& Hoefler, H. (2000). The use of molecular biology in diagnosis and prognosis of gastric cancer. Surg Oncol, 9, (1), pp. 5-11, ISSN 0960-7404

Belien, J. A., Buffart, T. E., Gill, A. J., Broeckaert, M. A., Quirke, P., Meijer, G. A. \& Grabsch, H. I. (2009). Gross genomic damage measured by DNA image cytometry 
independently predicts gastric cancer patient survival. Br J Cancer, 101, (6), pp. 1011-1018, ISSN 1532-1827

Birkbak, N. J., Eklund, A. C., Li, Q., McClelland, S. E., Endesfelder, D., Tan, P., Tan, I. B., Richardson, A. L., Szallasi, Z. \& Swanton, C. (2011). Paradoxical relationship between chromosomal instability and survival outcome in cancer. Cancer Res, pp., ISSN 1538-7445

Blasi, M. F., Ventura, I., Aquilina, G., Degan, P., Bertario, L., Bassi, C., Radice, P. \& Bignami, M. (2006). A human cell-based assay to evaluate the effects of alterations in the MLH1 mismatch repair gene. Cancer Res, 66, (18), pp. 9036-9044, ISSN 0008-5472

Boland, C. R., Thibodeau, S. N., Hamilton, S. R., Sidransky, D., Eshleman, J. R., Burt, R. W., Meltzer, S. J., Rodriguez-Bigas, M. A., Fodde, R., Ranzani, G. N. \& Srivastava, S. (1998). A National Cancer Institute Workshop on Microsatellite Instability for cancer detection and familial predisposition: development of international criteria for the determination of microsatellite instability in colorectal cancer. Cancer Res, 58, (22), pp. 5248-5257, ISSN 0008-5472

Boland, C. R. \& Goel, A. (2010). Microsatellite instability in colorectal cancer. Gastroenterology, 138, (6), pp. 2073-2087 e2073, ISSN 1528-0012

Brown, L. F., Berse, B., Jackman, R. W., Tognazzi, K., Manseau, E. J., Senger, D. R. \& Dvorak, H. F. (1993). Expression of vascular permeability factor (vascular endothelial growth factor) and its receptors in adenocarcinomas of the gastrointestinal tract. Cancer Res, 53, (19), pp. 4727-4735, ISSN 0008-5472

Buermeyer, A. B., Deschenes, S. M., Baker, S. M. \& Liskay, R. M. (1999). Mammalian DNA mismatch repair. Annu Rev Genet, 33, pp. 533-564, ISSN 0066-4197

Buffart, T. E., Carvalho, B., Hopmans, E., Brehm, V., Kranenbarg, E. K., Schaaij-Visser, T. B., Eijk, P. P., van Grieken, N. C., Ylstra, B., van de Velde, C. J. \& Meijer, G. A. (2007a). Gastric cancers in young and elderly patients show different genomic profiles. $J$ Pathol, 211, (1), pp. 45-51, ISSN 0022-3417

Buffart, T. E., Carvalho, B., Mons, T., Reis, R. M., Moutinho, C., Silva, P., van Grieken, N. C., Vieth, M., Stolte, M., van de Velde, C. J., Schrock, E., Matthaei, A., Ylstra, B., Carneiro, F. \& Meijer, G. A. (2007b). DNA copy number profiles of gastric cancer precursor lesions. BMC Genomics, 8, pp. 345, ISSN 1471-2164

Buffart, T. E., Louw, M., van Grieken, N. C., Tijssen, M., Carvalho, B., Ylstra, B., Grabsch, H., Mulder, C. J., van de Velde, C. J., van der Merwe, S. W. \& Meijer, G. A. (2011). Gastric cancers of Western European and African patients show different patterns of genomic instability. BMC Med Genomics, 4, pp. 7, ISSN 1755-8794

Buhard, O., Suraweera, N., Lectard, A., Duval, A. \& Hamelin, R. (2004). Quasimonomorphic mononucleotide repeats for high-level microsatellite instability analysis. Dis Markers, 20, (4-5), pp. 251-257, ISSN 0278-0240

Buhard, O., Cattaneo, F., Wong, Y. F., Yim, S. F., Friedman, E., Flejou, J. F., Duval, A. \& Hamelin, R. (2006). Multipopulation analysis of polymorphisms in five mononucleotide repeats used to determine the microsatellite instability status of human tumors. J Clin Oncol, 24, (2), pp. 241-251, ISSN 1527-7755

Caca, K., Kolligs, F. T., Ji, X., Hayes, M., Qian, J., Yahanda, A., Rimm, D. L., Costa, J. \& Fearon, E. R. (1999). Beta- and gamma-catenin mutations, but not E-cadherin inactivation, underlie T-cell factor/lymphoid enhancer factor transcriptional 
deregulation in gastric and pancreatic cancer. Cell Growth Differ, 10, (6), pp. 369-376, ISSN 1044-9523

Castro, d. I. P., Carcer, d. G. \& Malumbres, M. (2007). A Census of Mitotic Cancer Genes: New Insights into Tumor Cell Biology and Cancer Therapy. Carcinogenesis, 28, (5), pp. 899-912

Chao, E. C., Velasquez, J. L., Witherspoon, M. S., Rozek, L. S., Peel, D., Ng, P., Gruber, S. B., Watson, P., Rennert, G., Anton-Culver, H., Lynch, H. \& Lipkin, S. M. (2008). Accurate classification of MLH1/MSH2 missense variants with multivariate analysis of protein polymorphisms-mismatch repair (MAPP-MMR). Hum Mutat, 29,

(6), pp. 852-860, ISSN 1098-1004

Crew, K. D. \& Neugut, A. I. (2006). Epidemiology of gastric cancer. World J Gastroenterol, 12, (3), pp. 354-362

Dang, V. T., Kassahn, K. S., Marcos, A. E. \& Ragan, M. A. (2008). Identification of human haploinsufficient genes and their genomic proximity to segmental duplications. Eur J Hum Genet, 16, (11), pp. 1350-1357, ISSN 1018-4813

Dar, A. A., Zaika, A., Piazuelo, M. B., Correa, P., Koyama, T., Belkhiri, A., Washington, K., Castells, A., Pera, M. \& El-Rifai, W. (2008). Frequent overexpression of Aurora Kinase $\mathrm{A}$ in upper gastrointestinal adenocarcinomas correlates with potent antiapoptotic functions. Cancer, 112, (8), pp. 1688-1698

Deng, G., Eh, Z., Xu, Y. \& Lu, Y. (1994). Activation of oncogene c-Ha-ras in gastric cancer of Chinese patients. Semin Surg Oncol, 10, (2), pp. 83-87, ISSN 8756-0437

Duesberg, P., Li, R., Rasnick, D., Rausch, C., Willer, A., Kraemer, A., Yerganian, G. \& Hehlmann, R. (2000). Aneuploidy precedes and segregates with chemical carcinogenesis. Cancer Genet Cytogenet, 119, (2), pp. 83-93, ISSN 0165-4608

Duesberg, P. \& Rasnick, D. (2000). Aneuploidy, the somatic mutation that makes cancer a species of its own. Cell Motil Cytoskeleton, 47, (2), pp. 81-107, ISSN 0886-1544

Duesberg, P. \& Li, R. (2003). Multistep carcinogenesis: a chain reaction of aneuploidizations. Cell Cycle, 2, (3), pp. 202-210, ISSN 1538-4101

Duesberg, P., Li, R., Fabarius, A. \& Hehlmann, R. (2005). The chromosomal basis of cancer. Cell Oncol, 27, (5-6), pp. 293-318

El-Omar, E. M., Rabkin, C. S., Gammon, M. D., Vaughan, T. L., Risch, H. A., Schoenberg, J. B., Stanford, J. L., Mayne, S. T., Goedert, J., Blot, W. J., Fraumeni, J. F., Jr. \& Chow, W. H. (2003). Increased risk of noncardia gastric cancer associated with proinflammatory cytokine gene polymorphisms. Gastroenterology, 124, (5), pp. 11931201, ISSN 0016-5085

Ellison, A. R., Lofing, J. \& Bitter, G. A. (2001). Functional analysis of human MLH1 and MSH2 missense variants and hybrid human-yeast MLH1 proteins in Saccharomyces cerevisiae. Hum Mol Genet, 10, (18), pp. 1889-1900

Fearon, E. R. \& Vogelstein, B. (1990). A genetic model for colorectal tumorigenesis. Cell, 61, (5), pp. 759-767, ISSN 0092-8674

Frank, S. A. (2004). Genetic predisposition to cancer - insights from population genetics. Nat Rev Genet, 5, (10), pp. 764-772, ISSN 1471-0056

Freiberg, E. C. (2003). DNA damage and repair. Nature, 421, pp. 436-440

French, A. J., Petroni, G., Thibideau, S. N., Smolkin, M., Bissonette, E., Roviello, F., Harper, J. C., Koch, B. R., Anderson, S. A., Hebbring, S. J. \& Powell, S. M. (2004). Allelic 
imbalance of $8 \mathrm{p}$ indicates poor survival in gastric cancer. J Mol Diagn, 6, (3), pp. 243-252, ISSN 1525-1578

Garcia, I., del Casar, J. M., Corte, M. D., Allende, M. T., Garcia-Muniz, J. L. \& Vizoso, F. (2003). Epidermal growth factor receptor and c-erbB-2 contents in unresectable (UICC R1 or R2) gastric cancer. Int J Biol Markers, 18, (3), pp. 200-206, ISSN 03936155

Gazvoda, B., Juvan, R., Zupanic-Pajnic, I., Repse, S., Ferlan-Marolt, K., Balazic, J. \& Komel, R. (2007). Genetic changes in Slovenian patients with gastric adenocarcinoma evaluated in terms of microsatellite DNA. Eur J Gastroenterol Hepatol, 19, (12), pp. 1082-1089

Globocan, I. A. f. R. o. C. (2011). Available from: http://globocan.iarc.fr/.

Gollin, S. M. (2005). Mechanisms leading to chromosomal instability. Semin Cancer Biol, 15, (1), pp. 33-42

Grabsch, H. I., Askham, J. M., Morrison, E. E., Pomjanski, N., Lickvers, K., Parsons, W. J., Boecking, A., Gabbert, H. E. \& Mueller, W. (2004). Expression of BUB1 protein in gastric cancer correlates with the histological subtype, but not with DNA ploidy or microsatellite instability. J Pathol, 202, (2), pp. 208-214, ISSN 0022-3417

Gu, M., Kim, D., Bae, Y., Choi, J., Kim, S. \& Song, S. (2009). Analysis of microsatellite instability, protein expression and methylation status of hMLH1 and hMSH2 genes in gastric carcinomas. Hepatogastroenterology, 56, (91-92), pp. 899-904, ISSN 01726390

Guilford, P., Hopkins, J., Harraway, J., McLeod, M., McLeod, N., Harawira, P., Taite, H., Scoular, R., Miller, A. \& Reeve, A. E. (1998). E-cadherin germline mutations in familial gastric cancer. Nature, 392, (6674), pp. 402-405, ISSN 0028-0836

Guerrette, S., Acharya, S. \& Fishel, R. (1999). The interaction of the human MutL homologues in hereditary nonpolyposis colon cancer. J Biol Chem, 274, (10), pp. 6336-6341, ISSN 0021-9258

Gylling, A., Abdel-Rahman, W. M., Juhola, M., Nuorva, K., Hautala, E., Jarvinen, H. J., Mecklin, J. P., Aarnio, M. \& Peltomaki, P. (2007). Is gastric cancer part of the tumour spectrum of hereditary non-polyposis colorectal cancer? A molecular genetic study. Gut, 56, (7), pp. 926-933, ISSN 0017-5749

Hamilton, J. P. \& Meltzer, S. J. (2006). A review of the genomics of gastric cancer. Clin Gastroenterol Hepatol, 4, (4), pp. 416-425, ISSN 1542-3565

Hara, T., Ooi, A., Kobayashi, M., Mai, M., Yanagihara, K. \& Nakanishi, I. (1998). Amplification of c-myc, K-sam, and c-met in gastric cancers: detection by fluorescence in situ hybridization. Lab Invest, 78, (9), pp. 1143-1153, ISSN 0023-6837

Hattori, Y., Itoh, H., Uchino, S., Hosokawa, K., Ochiai, A., Ino, Y., Ishii, H., Sakamoto, H., Yamaguchi, N., Yanagihara, K., Hirohashi, S., Sugimura, T. \& Terada, M. (1996). Immunohistochemical detection of K-sam protein in stomach cancer. Clin Cancer Res, 2, (8), pp. 1373-1381, ISSN 1078-0432

Hirohashi, S. \& Sugimura, T. (1991). Genetic alterations in human gastric cancer. Cancer Cells, 3, (2), pp. 49-52, ISSN 1042-2196

Hiyama, T., Haruma, K., Kitadai, Y., Masuda, H., Miyamoto, M., Tanaka, S., Yoshihara, M., Shimamoto, F. \& Chayama, K. (2002). K-ras mutation in helicobacter pyloriassociated chronic gastritis in patients with and without gastric cancer. Int J Cancer, 97, (5), pp. 562-566, ISSN 0020-7136 
Hong, S. J., Jeon, E. J., Oh, J. H., Seo, E. J., Choi, S. W. \& Rhyu, M. G. (2010). The genereduction effect of chromosomal losses detected in gastric cancers. BMC Gastroenterol, 10, pp. 138

Hou, Q., Wu, Y. H., Grabsch, H., Zhu, Y., Leong, S. H., Ganesan, K., Cross, D., Tan, L. K., Tao, J., Gopalakrishnan, V., Tang, B. L., Kon, O. L. \& Tan, P. (2008). Integrative genomics identifies RAB23 as an invasion mediator gene in diffuse-type gastric cancer. Cancer Res, 68, (12), pp. 4623-4630, ISSN 1538-7445

Hudler, P., Vouk, K., Liovic, M., Repse, S., Juvan, R. \& Komel, R. (2004). Mutations in the hMLH1 gene in Slovenian patients with gastric carcinoma. Clin Genet, 65, (5), pp. 405-411

Hudler, P., Kastelic, S., Frkovic-Grazio, S. \& Komel, R. (2009). Polymorphisms in AURKA gene in Slovenian patients with gastric cancer. (Preliminary report). Proceedings of Joint Congress of the Slovenian Biochemical Society and the Genetic Society of Slovenia with International Participation, Otocec, September, 2009

Hudler, P., Simic, M., Frkovic-Grazio, S. \& Komel, R. (2010). Polymorphisms in TTK and BUB1B genes in Slovenian patients with gastric cancer. (Preliminary report). Proceedings of $5^{\text {th }}$ CFGBC Symposium, Ljubljana, June 2010

Imai, K. \& Yamamoto, H. (2008). Carcinogenesis and microsatellite instability: the interrelationship between genetics and epigenetics. Carcinogenesis, 29, (4), pp. 673680, ISSN 1460-2180

Iovino, F., Lentini, L., Amato, A. \& Di Leonardo, A. (2006). RB acute loss induces centrosome amplification and aneuploidy in murine primary fibroblasts. Mol Cancer, 5, pp. 38, ISSN 1476-4598

Jiaqing, L., Hokita, S., Xiangming, C., Natsugoe, S., Tanabe, G., Baba, M., Takao, S. \& Aikou, T. (1998). Role of cyclin E and p53 expression in progression of early gastric cancer. Gastric Cancer, 1, (2), pp. 160-165, ISSN 1436-3291

Junnila, S., Kokkola, A., Karjalainen-Lindsberg, M. L., Puolakkainen, P. \& Monni, O. (2010). Genome-wide gene copy number and expression analysis of primary gastric tumors and gastric cancer cell lines. BMC Cancer, 10, pp. 73, ISSN 1471-2407

Juvan, R., Hudler, P., Gazvoda, B., Repse, S., Bracko, M. \& Komel, R. (2007). Significance of genetic abnormalities of $\mathrm{p} 53$ protein in Slovenian patients with gastric carcinoma. Croat Med J, 48, (2), pp. 207-217, ISSN 1332-8166

Kanai, Y. \& Hirohashi, S. (1997). Invasion and metastasis, In: Gastric cancer, T. Sugimura, pp. 109, Oxford University Press, Oxford.

Kang, J. U., Kang, J. J., Kwon, K. C., Park, J. W., Jeong, T. E., Noh, S. M. \& Koo, S. H. (2006). Genetic alterations in primary gastric carcinomas correlated with clinicopathological variables by array comparative genomic hybridization. J Korean Med Sci, 21, (4), pp. 656-665, ISSN 1011-8934

Kim, H. S., Lee, B. L., Woo, D. K., Bae, S. I. \& Kim, W. H. (2001). Assessment of markers for the identification of microsatellite instability phenotype in gastric neoplasms. Cancer Lett, 164, (1), pp. 61-68, ISSN 0304-3835

Kim, J. H., Takahashi, T., Chiba, I., Park, J. G., Birrer, M. J., Roh, J. K., De Lee, H., Kim, J. P., Minna, J. D. \& Gazdar, A. F. (1991). Occurrence of p53 gene abnormalities in gastric carcinoma tumors and cell lines. J Natl Cancer Inst, 83, (13), pp. 938-943

Kimura, Y., Noguchi, T., Kawahara, K., Kashima, K., Daa, T. \& Yokoyama, S. (2004). Genetic alterations in 102 primary gastric cancers by comparative genomic hybridization: 
gain of 20q and loss of 18q are associated with tumor progression. Mod Pathol, 17, (11), pp. 1328-1337, ISSN 0893-3952

Kinzler, K. W., Nilbert, M. C., Su, L. K., Vogelstein, B., Bryan, T. M., Levy, D. B., Smith, K. J., Preisinger, A. C., Hedge, P., McKechnie, D. \& et al. (1991). Identification of FAP locus genes from chromosome 5q21. Science, 253, (5020), pp. 661-665, ISSN 00368075

Knudson, A. G. (1993). Antioncogenes and human cancer. Proc Natl Acad Sci U S A, 90, (23), pp. 10914-10921, ISSN 0027-8424

Kondo, T., Oue, N., Mitani, Y., Kuniyasu, H., Noguchi, T., Kuraoka, K., Nakayama, H. \& Yasui, W. (2005). Loss of heterozygosity and histone hypoacetylation of the PINX1 gene are associated with reduced expression in gastric carcinoma. Oncogene, 24, (1), pp. 157-164, ISSN 0950-9232

Kondo, E., Suzuki, H., Horii, A. \& Fukushige, S. (2003). A yeast two-hybrid assay provides a simple way to evaluate the vast majority of hMLH1 germ-line mutations. Cancer Res, 63, (12), pp. 3302-3308, ISSN 0008-5472

Koo, S. H., Jeong, T. E., Kang, J., Kwon, K. C., Park, J. W. \& Noh, S. M. (2004). Prognostic implications for gastric carcinoma based on loss of heterozygosity genotypes correlation with clinicopathologic variables. Cancer Genet Cytogenet, 153, (1), pp. 2631, ISSN 0165-4608

Kumar, P., Henikoff, S. \& Ng, P. C. (2009). Predicting the effects of coding non-synonymous variants on protein function using the SIFT algorithm. Nat Protoc, 4, (7), pp. 10731081

Kufe, D. W., Holland, J. F., Frei, E., Abramson, D. H., Dang, C. T., DeAngelis, L. M., Dolphin, K. W., Gilewski, T. A., Holland, J. C., Silver, R. T. \& American Cancer Society. (2003). Cancer medicine 6, BC Decker, ISBN 1550092138, Hamilton, Ont.

Lawes, D. A., SenGupta, S. \& Boulos, P. B. (2003). The clinical importance and prognostic implications of microsatellite instability in sporadic cancer. Eur J Surg Oncol, 29, (3), pp. 201-212, ISSN 0748-7983

Lazar, D., Taban, S., Sporea, I., Dema, A., Cornianu, M., Lazar, E., Goldis, A., Ratiu, I. \& Vernic, C. (2010). The immunohistochemical expression of the p53-protein in gastric carcinomas. Correlation with clinicopathological factors and survival of patients. Rom J Morphol Embryol, 51, (2), pp. 249-257, ISSN 1220-0522

Leite, M., Corso, G., Sousa, S., Milanezi, F., Afonso, L. P., Henrique, R., Soares, J. M., Castedo, S., Carneiro, F., Roviello, F., Oliveira, C. \& Seruca, R. (2011). MSI phenotype and MMR alterations in familial and sporadic gastric cancer. Int $J$ Cancer, 128, (7), pp. 1606-1613, ISSN 1097-0215

Leung, S. Y., Yuen, S. T., Chung, L. P., Chu, K. M., Chan, A. S. \& Ho, J. C. (1999). hMLH1 promoter methylation and lack of hMLH1 expression in sporadic gastric carcinomas with high-frequency microsatellite instability. Cancer Res, 59, (1), pp. 159-164, ISSN 0008-5472

Liu, X. P., Tsushimi, K., Tsushimi, M., Oga, A., Kawauchi, S., Furuya, T. \& Sasaki, K. (2001). Expression of p53 protein as a prognostic indicator of reduced survival time in diffuse-type gastric carcinoma. Pathol Int, 51, (6), pp. 440-444

Loeb, L. A. (2001). A mutator phenotype in cancer. Cancer Res, 61, (8), pp. 3230-3239, ISSN $0008-5472$ 
Lynch, H. T. \& Lynch, J. F. (1998). Genetics of colonic cancer. Digestion, 59, (5), pp. 481-492, ISSN 0012-2823

Malden, L. T., Novak, U. \& Burgess, A. W. (1989). Expression of transforming growth factor alpha messenger RNA in the normal and neoplastic gastro-intestinal tract. Int $J$ Cancer, 43, (3), pp. 380-384, ISSN 0020-7136

Mathe, E., Olivier, M., Kato, S., Ishioka, C., Hainaut, P. \& Tavtigian, S. V. (2006). Computational approaches for predicting the biological effect of p53 missense mutations: a comparison of three sequence analysis based methods. Nucleic Acids Res, 34, (5), pp. 1317-1325, ISSN 1362-4962

Martin, S. A., Hewish, M., Lord, C. J. \& Ashworth, A. (2010). Genomic instability and the selection of treatments for cancer. J Pathol, 220, (2), pp. 281-289, ISSN 1096-9896

Matysiak-Budnik, T. \& Megraud, F. (2006). Helicobacter pylori infection and gastric cancer. Eur J Cancer, 42, (6), pp. 708-716, ISSN 0959-8049

Milne, A. N., Carneiro, F., O'Morain, C. \& Offerhaus, G. J. (2009). Nature meets nurture: molecular genetics of gastric cancer. Hum Genet, 126, (5), pp. 615-628, ISSN 14321203

Mitani, Y., Oue, N., Hamai, Y., Aung, P. P., Matsumura, S., Nakayama, H., Kamata, N. \& Yasui, W. (2005). Histone H3 acetylation is associated with reduced p21(WAF1/CIP1) expression by gastric carcinoma. J Pathol, 205, (1), pp. 65-73, ISSN 0022-3417

Morohara, K., Nakao, K., Tajima, Y., Nishino, N., Yamazaki, K., Kaetsu, T., Suzuki, S., Tsunoda, A., Kawamura, M., Aida, T., Tachikawa, T. \& Kusano, M. (2005). Analysis by comparative genomic hybridization of gastric cancer with peritoneal dissemination and/or positive peritoneal cytology. Cancer Genet Cytogenet, 161, (1), pp. 57-62, ISSN 0165-4608

Nakajima, M., Sawada, H., Yamada, Y., Watanabe, A., Tatsumi, M., Yamashita, J., Matsuda, M., Sakaguchi, T., Hirao, T. \& Nakano, H. (1999). The prognostic significance of amplification and overexpression of c-met and c-erb B-2 in human gastric carcinomas. Cancer, 85, (9), pp. 1894-1902

Ng, P. C. \& Henikoff, S. (2003). SIFT: Predicting amino acid changes that affect protein function. Nucleic Acids Res, 31, (13), pp. 3812-3814, ISSN 1362-4962

Nobili, S., Bruno, L., Landini, I., Napoli, C., Bechi, P., Tonelli, F., Rubio, C. A., Mini, E. \& Nesi, G. (2011). Genomic and genetic alterations influence the progression of gastric cancer. World J Gastroenterol, 17, (3), pp. 290-299, ISSN 1007-9327

Oda, S., Zhao, Y. \& Maehara, Y. (2005). Microsatellite instability in gastrointestinal tract cancers: a brief update. Surg Today, 35, (12), pp. 1005-1015, ISSN 0941-1291

Osaki, M., Miyata, H., Hayashi, A., Gomyo, Y., Tatebe, S. \& Ito, H. (1996). Lack of rearranged Tpr-met mRNA expression in human gastric cancer cell lines and gastric mucosa and carcinoma. Anticancer Res, 16, (5A), pp. 2881-2884, ISSN 02507005

Ottini, L., Falchetti, M., Saieva, C., De Marco, M., Masala, G., Zanna, I., Paglierani, M., Giannini, G., Gulino, A., Nesi, G., Mariani Costantini, R. \& Palli, D. (2004). MRE11 expression is impaired in gastric cancer with microsatellite instability. Carcinogenesis, 25, (12), pp. 2337-2343, ISSN 0143-3334 
Ottini, L., Falchetti, M., Lupi, R., Rizzolo, P., Agnese, V., Colucci, G., Bazan, V. \& Russo, A. (2006). Patterns of genomic instability in gastric cancer: clinical implications and perspectives. Ann Oncol, 17, (suppl_7), pp. vii97-vii102

Ou, J., Niessen, R. C., Lutzen, A., Sijmons, R. H., Kleibeuker, J. H., de Wind, N., Rasmussen, L. J. \& Hofstra, R. M. (2007). Functional analysis helps to clarify the clinical importance of unclassified variants in DNA mismatch repair genes. Hum Mutat, 28, (11), pp. 1047-1054, ISSN 1098-1004

Oue, N., Sentani, K., Yokozaki, H., Kitadai, Y., Ito, R. \& Yasui, W. (2001). Promoter methylation status of the DNA repair genes hMLH1 and MGMT in gastric carcinoma and metaplastic mucosa. Pathobiology, 69, (3), pp. 143-149, ISSN 10152008

Panani, A. D. (2008). Cytogenetic and molecular aspects of gastric cancer: clinical implications. Cancer Lett, 266, (2), pp. 99-115, ISSN 0304-3835

Park, W. S., Oh, R. R., Park, J. Y., Lee, S. H., Shin, M. S., Kim, Y. S., Kim, S. Y., Lee, H. K., Kim, P. J., Oh, S. T., Yoo, N. J. \& Lee, J. Y. (1999). Frequent somatic mutations of the beta-catenin gene in intestinal-type gastric cancer. Cancer Res, 59, (17), pp. 42574260, ISSN 0008-5472

Pedrazzani, C., Corso, G., Velho, S., Leite, M., Pascale, V., Bettarini, F., Marrelli, D., Seruca, R. \& Roviello, F. (2009). Evidence of tumor microsatellite instability in gastric cancer with familial aggregation. Fam Cancer, 8, (3), pp. 215-220, ISSN 1573-7292

Pellegata, N. S., Losekoot, M., Fodde, R., Pugliese, V., Saccomanno, S., Renault, B., Bernini, L. F. \& Ranzani, G. N. (1992). Detection of K-ras mutations by denaturing gradient gel electrophoresis (DGGE): a study on pancreatic cancer. Anticancer Res, 12, (5), pp. 1731-1735, ISSN 0250-7005

Perera, S. \& Bapat, B. (2008). The MLH1 variants p.Arg265Cys and p.Lys618Ala affect protein stability while p.Leu749Gln affects heterodimer formation. Hum Mutat, 29, (2), pp. 332, ISSN 1098-1004

Percesepe, A., Borghi, F., Menigatti, M., Losi, L., Foroni, M., Di Gregorio, C., Rossi, G., Pedroni, M., Sala, E., Vaccina, F., Roncucci, L., Benatti, P., Viel, A., Genuardi, M., Marra, G., Kristo, P., Peltomaki, P. \& Ponz de Leon, M. (2001). Molecular screening for hereditary nonpolyposis colorectal cancer: a prospective, population-based study. J Clin Oncol, 19, (19), pp. 3944-3950

Perucho, M. (1996). Microsatellite instability: the mutator that mutates the other mutator. Nat Med, 2, (6), pp. 630-631, ISSN 1078-8956

Pino, M. S. \& Chung, D. C. (2010). The chromosomal instability pathway in colon cancer. Gastroenterology, 138, (6), pp. 2059-2072, ISSN 1528-0012

Rajcevic, U., Juvan, R., Gazvoda, B., Repse, S. \& Komel, R. (2001). Assessment of differential expression of oncogenes in gastric adenocarcinoma by fluorescent multiplex RTPCR assay. Pflugers Arch, 442, (6 Suppl 1), pp. R190-192, ISSN 0031-6768

Rajcevic, U., Hudler, P., Mijovski, G., Gorjanc, G., Hoelzl, G., Repse, S., Juvan, R., Kovac, M., Huber, C. G. \& Komel, R. (2007). Assessment of differential expression of oncogenes in adenocarcinoma of stomach with fluorescent labeling and simultaneous amplification of gene transcripts. Radiol Oncol, 41, (4), pp. 174-182

Raevaara, T. E., Korhonen, M. K., Lohi, H., Hampel, H., Lynch, E., Lonnqvist, K. E., Holinski-Feder, E., Sutter, C., McKinnon, W., Duraisamy, S., Gerdes, A. M., Peltomaki, P., Kohonen-Ccorish, M., Mangold, E., Macrae, F., Greenblatt, M., de la 
Chapelle, A. \& Nystrom, M. (2005). Functional significance and clinical phenotype of nontruncating mismatch repair variants of MLH1. Gastroenterology, 129, (2), pp. 537-549, ISSN 0016-5085

Ramensky, V., Bork, P. \& Sunyaev, S. (2002). Human non-synonymous SNPs: server and survey. Nucleic Acids Res, 30, (17), pp. 3894-3900, ISSN 1362-4962

Resende, C., Ristimaki, A. \& Machado, J. C. (2010). Genetic and epigenetic alteration in gastric carcinogenesis. Helicobacter, 15 Suppl 1, pp. 34-39, ISSN 1523-5378

Ricke, R. M., van Ree, J. H. \& van Deursen, J. M. (2008). Whole chromosome instability and cancer: a complex relationship. Trends Genet, 24, (9), pp. 457-466, ISSN 0168-9525

Russo, A., Bazan, V., Migliavacca, M., Zanna, I., Tubiolo, C., Tumminello, F. M., Dardanoni, G., Cajozzo, M., Bazan, P., Modica, G., Latteri, M., Tomasino, R. M., Colucci, G., Gebbia, N. \& Leto, G. (2000). Prognostic significance of DNA ploidy, S-phase fraction, and tissue levels of aspartic, cysteine, and serine proteases in operable gastric carcinoma. Clin Cancer Res, 6, (1), pp. 178-184, ISSN 1078-0432

Samowitz, W. S., Curtin, K., Lin, H. H., Robertson, M. A., Schaffer, D., Nichols, M., Gruenthal, K., Leppert, M. F. \& Slattery, M. L. (2001). The colon cancer burden of genetically defined hereditary nonpolyposis colon cancer. Gastroenterology, 121, (4), pp. 830-838, ISSN 0016-5085

Scartozzi, M., Galizia, E., Freddari, F., Berardi, R., Cellerino, R. \& Cascinu, S. (2004). Molecular biology of sporadic gastric cancer: prognostic indicators and novel therapeutic approaches. Cancer Treat Rev, 30, (5), pp. 451-459, ISSN 0305-7372

Schmit, T. L. \& Ahmad, N. (2007). Regulation of mitosis via mitotic kinases: new opportunities for cancer management. Mol Cancer Ther, 6, (7), pp. 1920-1931, ISSN 1535-7163

Schneider, B. G., Bravo, J. C., Roa, J. C., Roa, I., Kim, M. C., Lee, K. M., Plaisance, K. T., Jr., McBride, C. M. \& Mera, R. (2000). Microsatellite instability, prognosis and metastasis in gastric cancers from a low-risk population. Int J Cancer, 89, (5), pp. 444-452, ISSN 0020-7136

Schneider, B. G., Peng, D. F., Camargo, M. C., Piazuelo, M. B., Sicinschi, L. A., Mera, R., Romero-Gallo, J., Delgado, A. G., Bravo, L. E., Wilson, K. T., Peek, R. M., Jr., Correa, P. \& El-Rifai, W. (2010). Promoter DNA hypermethylation in gastric biopsies from subjects at high and low risk for gastric cancer. Int J Cancer, 127, (11), pp. 2588-2597, ISSN 1097-0215

Sharp, A., Pichert, G., Lucassen, A. \& Eccles, D. (2004). RNA analysis reveals splicing mutations and loss of expression defects in MLH1 and BRCA1. Hum Mutat, 24, (3), pp. 272, ISSN 1098-1004

Shepard, J. L., Amatruda, J. F., Finkelstein, D., Ziai, J., Finley, K. R., Stern, H. M., Chiang, K., Hersey, C., Barut, B., Freeman, J. L., Lee, C., Glickman, J. N., Kutok, J. L., Aster, J. C. \& Zon, L. I. (2007). A mutation in separase causes genome instability and increased susceptibility to epithelial cancer. Genes Dev, 21, (1), pp. 55-59

Shimodaira, H., Filosi, N., Shibata, H., Suzuki, T., Radice, P., Kanamaru, R., Friend, S. H., Kolodner, R. D. \& Ishioka, C. (1998). Functional analysis of human MLH1 mutations in Saccharomyces cerevisiae. Nat Genet, 19, (4), pp. 384-389

Simpson, A. J., Caballero, O. L. \& Pena, S. D. (2001). Microsatellite instability as a tool for the classification of gastric cancer. Trends Mol Med, 7, (2), pp. 76-80, ISSN 1471-4914 
Smith, M. G., Hold, G. L., Tahara, E. \& El-Omar, E. M. (2006). Cellular and molecular aspects of gastric cancer. World J Gastroenterol, 12, (19), pp. 2979-2990

Smolen, G. A., Sordella, R., Muir, B., Mohapatra, G., Barmettler, A., Archibald, H., Kim, W. J., Okimoto, R. A., Bell, D. W., Sgroi, D. C., Christensen, J. G., Settleman, J. \& Haber, D. A. (2006). Amplification of MET may identify a subset of cancers with extreme sensitivity to the selective tyrosine kinase inhibitor PHA-665752. Proc Natl Acad Sci U S A, 103, (7), pp. 2316-2321, ISSN 0027-8424

Soh, K., Yanagisawa, A., Hiratsuka, H., Sugano, H. \& Kato, Y. (1993). Variation in K-ras codon 12 point mutation rate with histological atypia within individual colorectal tumors. Jpn J Cancer Res, 84, (4), pp. 388-393, ISSN 0910-5050

Suraweera, N., Duval, A., Reperant, M., Vaury, C., Furlan, D., Leroy, K., Seruca, R., Iacopetta, B. \& Hamelin, R. (2002). Evaluation of tumor microsatellite instability using five quasimonomorphic mononucleotide repeats and pentaplex PCR. Gastroenterology, 123, (6), pp. 1804-1811, ISSN 0016-5085

Suzuki, K., Ohnami, S., Tanabe, C., Sasaki, H., Yasuda, J., Katai, H., Yoshimura, K., Terada, M., Perucho, M. \& Yoshida, T. (2003). The genomic damage estimated by arbitrarily primed PCR DNA fingerprinting is useful for the prognosis of gastric cancer. Gastroenterology, 125, (5), pp. 1330-1340, ISSN 0016-5085

Suzuki, K., Suzuki, I., Leodolter, A., Alonso, S., Horiuchi, S., Yamashita, K. \& Perucho, M. (2006). Global DNA demethylation in gastrointestinal cancer is age dependent and precedes genomic damage. Cancer Cell, 9, (3), pp. 199-207

Tahara, E. (1995). Genetic alterations in human gastrointestinal cancers. The application to molecular diagnosis. Cancer, 75, (6 Suppl), pp. 1410-1417

Tahara, E. (2004). Genetic pathways of two types of gastric cancer. IARC Sci Publ, (157), pp. 327-349

Tahara, E. (2008). Abnormal growth factor/cytokine network in gastric cancer. Cancer Microenviron, 1, (1), pp. 85-91, ISSN 1875-2292

Takahashi, M., Shimodaira, H., Andreutti-Zaugg, C., Iggo, R., Kolodner, R. D. \& Ishioka, C. (2007). Functional analysis of human MLH1 variants using yeast and in vitro mismatch repair assays. Cancer Res, 67, (10), pp. 4595-4604, ISSN 0008-5472

Tamura, G. (2006). Alterations of tumor suppressor and tumor-related genes in the development and progression of gastric cancer. World J Gastroenterol, 12, (2), pp. 192-198

Tavtigian, S. V., Greenblatt, M. S., Lesueur, F. \& Byrnes, G. B. (2008). In silico analysis of missense substitutions using sequence-alignment based methods. Hum Mutat, 29, (11), pp. 1327-1336, ISSN 1098-1004

Tian, X., Song, S., Wu, J., Meng, L., Dong, Z. \& Shou, C. (2001). Vascular endothelial growth factor: acting as an autocrine growth factor for human gastric adenocarcinoma cell MGC803. Biochem Biophys Res Commun, 286, (3), pp. 505-512

Tomonaga, T. \& Nomura, F. (2007). Chromosome instability and kinetochore dysfunction. Histol Histopathol, 22, (2), pp. 191-197

Tournier, I., Vezain, M., Martins, A., Charbonnier, F., Baert-Desurmont, S., Olschwang, S., Wang, Q., Buisine, M. P., Soret, J., Tazi, J., Frebourg, T. \& Tosi, M. (2008). A large fraction of unclassified variants of the mismatch repair genes MLH1 and MSH2 is associated with splicing defects. Hum Mutat, 29, (12), pp. 1412-1424 
Trojan, J., Zeuzem, S., Randolph, A., Hemmerle, C., Brieger, A., Raedle, J., Plotz, G., Jiricny, J. \& Marra, G. (2002). Functional analysis of hMLH1 variants and HNPCC-related mutations using a human expression system. Gastroenterology, 122, (1), pp. 211-219

Tsugawa, K., Yonemura, Y., Hirono, Y., Fushida, S., Kaji, M., Miwa, K., Miyazaki, I. \& Yamamoto, H. (1998). Amplification of the c-met, c-erbB-2 and epidermal growth factor receptor gene in human gastric cancers: correlation to clinical features. Oncology, 55, (5), pp. 475-481, ISSN 0030-2414

Tsukamoto, Y., Uchida, T., Karnan, S., Noguchi, T., Nguyen, L. T., Tanigawa, M., Takeuchi, I., Matsuura, K., Hijiya, N., Nakada, C., Kishida, T., Kawahara, K., Ito, H., Murakami, K., Fujioka, T., Seto, M. \& Moriyama, M. (2008). Genome-wide analysis of DNA copy number alterations and gene expression in gastric cancer. J Pathol, 216, (4), pp. 471-482, ISSN 1096-9896

Umar, A., Boland, C. R., Terdiman, J. P., Syngal, S., de la Chapelle, A., Ruschoff, J., Fishel, R., Lindor, N. M., Burgart, L. J., Hamelin, R., Hamilton, S. R., Hiatt, R. A., Jass, J., Lindblom, A., Lynch, H. T., Peltomaki, P., Ramsey, S. D., Rodriguez-Bigas, M. A., Vasen, H. F., Hawk, E. T., Barrett, J. C., Freedman, A. N. \& Srivastava, S. (2004). Revised Bethesda Guidelines for hereditary nonpolyposis colorectal cancer (Lynch syndrome) and microsatellite instability. J Natl Cancer Inst, 96, (4), pp. 261-268, ISSN 1460-2105

van Rees, B. P., Musler, A., Caspers, E., Drillenburg, P., Craanen, M. E., Polkowski, W., Chibowski, D. \& Offerhaus, G. J. (1999). K-ras mutations in gastric stump carcinomas and in carcinomas from the non-operated stomach. Hepatogastroenterology, 46, (27), pp. 2063-2068, ISSN 0172-6390

Varis, A., van Rees, B., Weterman, M., Ristimaki, A., Offerhaus, J. \& Knuutila, S. (2003). DNA copy number changes in young gastric cancer patients with special reference to chromosome 19. Br J Cancer, 88, (12), pp. 1914-1919, ISSN 0007-0920

Vizoso, F. J., Corte, M. D., Alvarez, A., Garcia, I., del Casar, J. M., Bongera, M., Gonzalez, L. O., Garcia-Muniz, J. L. \& Allende, M. T. (2004). Membranous levels of c-erbB-2 oncoprotein in gastric cancer: their relationship with clinicopathological parameters and their prognostic significance. Int J Biol Markers, 19, (4), pp. 268-274, ISSN 03936155

Vogelsang, M., Comino, A., Zupanec, N., Hudler, P. \& Komel, R. (2009). Assessing pathogenicity of MLH1 variants by co-expression of human MLH1 and PMS2 genes in yeast. BMC Cancer, 9, pp. 382, ISSN 1471-2407

Vogelsang, M. \& Komel, R. (2010). Non-truncating hMLH1 variants identified in Slovenian gastric cancer patients are not associated with Lynch Syndrome: a functional analysis report. Fam Cancer, pp., ISSN 1573-7292

Vogelstein, B. \& Kinzler, K. W. (2004). Cancer genes and the pathways they control. Nat Med, 10, (8), pp. 789-799

Vousden, K. H. \& Prives, C. (2005). P53 and prognosis: new insights and further complexity. Cell, 120, (1), pp. 7-10, ISSN 0092-8674

Wanat, J. J., Singh, N. \& Alani, E. (2007). The effect of genetic background on the function of Saccharomyces cerevisiae mlh1 alleles that correspond to HNPCC missense mutations. Hum Mol Genet, 16, (4), pp. 445-452, ISSN 0964-6906

Weber, B. L. (2002). Cancer genomics. Cancer Cell, 1, (1), pp. 37-47, ISSN 1535-6108 
Weiss, M. M., Kuipers, E. J., Postma, C., Snijders, A. M., Pinkel, D., Meuwissen, S. G., Albertson, D. \& Meijer, G. A. (2004). Genomic alterations in primary gastric adenocarcinomas correlate with clinicopathological characteristics and survival. Cell Oncol, 26, (5-6), pp. 307-317, ISSN 1570-5870

Werner, M., Becker, K. F., Keller, G. \& Hofler, H. (2001). Gastric adenocarcinoma: pathomorphology and molecular pathology. J Cancer Res Clin Oncol, 127, (4), pp. 207-216, ISSN 0171-5216

Wright, P. A. \& Williams, G. T. (1993). Molecular biology and gastric carcinoma. Gut, 34, (2), pp. 145-147, ISSN 0017-5749

Wu, C. W., Chen, G. D., Fann, C. S., Lee, A. F., Chi, C. W., Liu, J. M., Weier, U. \& Chen, J. Y. (2002). Clinical implications of chromosomal abnormalities in gastric adenocarcinomas. Genes Chromosomes Cancer, 35, (3), pp. 219-231, ISSN 1045-2257

Wu, M. S., Lee, C. W., Shun, C. T., Wang, H. P., Lee, W. J., Chang, M. C., Sheu, J. C. \& Lin, J. T. (2000). Distinct clinicopathologic and genetic profiles in sporadic gastric cancer with different mutator phenotypes. Genes Chromosomes Cancer, 27, (4), pp. 403-411, ISSN 1045-2257

Wu, W. K., Cho, C. H., Lee, C. W., Fan, D., Wu, K., Yu, J. \& Sung, J. J. (2010). Dysregulation of cellular signaling in gastric cancer. Cancer Lett, 295, (2), pp. 144-153, ISSN 18727980

Xiangming, C., Hokita, S., Natsugoe, S., Tanabe, G., Baba, M., Takao, S., Kuroshima, K. \& Aikou, T. (1999). Cooccurrence of reduced expression of alpha-catenin and overexpression of p53 is a predictor of lymph node metastasis in early gastric cancer. Oncology, 57, (2), pp. 131-137, ISSN 0030-2414

Xiangming, C., Natsugoe, S., Takao, S., Hokita, S., Tanabe, G., Baba, M., Kuroshima, K. \& Aikou, T. (2000). The cooperative role of p27 with cyclin E in the prognosis of advanced gastric carcinoma. Cancer, 89, (6), pp. 1214-1219

Yamamoto, E., Suzuki, H., Takamaru, H., Yamamoto, H., Toyota, M. \& Shinomura, Y. (2011). Role of DNA Methylation in the Development of Diffuse-Type Gastric Cancer. Digestion, 83, (4), pp. 241-249, ISSN 1421-9867

Yamamoto, H., Perez-Piteira, J., Yoshida, T., Terada, M., Itoh, F., Imai, K. \& Perucho, M. (1999). Gastric cancers of the microsatellite mutator phenotype display characteristic genetic and clinical features. Gastroenterology, 116, (6), pp. 1348-1357, ISSN 0016-5085

Yamamoto, S., Yasui, W., Kitadai, Y., Yokozaki, H., Haruma, K., Kajiyama, G. \& Tahara, E. (1998). Expression of vascular endothelial growth factor in human gastric carcinomas. Pathol Int, 48, (7), pp. 499-506, ISSN 1320-5463

Yamashita, K., Sakuramoto, S. \& Watanabe, M. (2011). Genomic and epigenetic profiles of gastric cancer: potential diagnostic and therapeutic applications. Surg Today, 41, (1), pp. 24-38, ISSN 1436-2813

Yasa, M. H., Bektas, A., Yukselen, V., Akbulut, H., Camci, C. \& Ormeci, N. (2005). DNA analysis and DNA ploidy in gastric cancer and gastric precancerous lesions. Int J Clin Pract, 59, (9), pp. 1029-1033, ISSN 1368-5031

Yasui, W., Tahara, E., Tahara, H., Fujimoto, J., Naka, K., Nakayama, J., Ishikawa, F. \& Ide, T. (1999). Immunohistochemical detection of human telomerase reverse transcriptase in normal mucosa and precancerous lesions of the stomach. Jpn J Cancer Res, 90, (6), pp. 589-595, ISSN 0910-5050 
Yokozaki, H., Yasui, W. \& Tahara, E. (2001). Genetic and epigenetic changes in stomach cancer. Int Rev Cytol, 204, pp. 49-95, ISSN 0074-7696

Yonemura, Y., Takamura, H., Ninomiya, I., Fushida, S., Tsugawa, K., Kaji, M., Nakai, Y., Ohoyama, S., Yamaguchi, A. \& Miyazaki, I. (1992). Interrelationship between transforming growth factor-alpha and epidermal growth factor receptor in advanced gastric cancer. Oncology, 49, (2), pp. 157-161, ISSN 0030-2414

Yoshida, K., Yasui, W., Ito, H. \& Tahara, E. (1990). Growth factors in progression of human esophageal and gastric carcinomas. Exp Pathol, 40, (4), pp. 291-300, ISSN 0232-1513

Zhang, X. L., Yang, Y. S., Xu, D. P., Qu, J. H., Guo, M. Z., Gong, Y. \& Huang, J. (2009). Comparative study on overexpression of HER2/neu and HER3 in gastric cancer. World J Surg, 33, (10), pp. 2112-2118, ISSN 1432-2323

Zheng, L., Wang, L., Ajani, J. \& Xie, K. (2004). Molecular basis of gastric cancer development and progression. Gastric Cancer, 7, (2), pp. 61-77

Zhou, X. P., Hoang, J. M., Li, Y. J., Seruca, R., Carneiro, F., Sobrinho-Simoes, M., Lothe, R. A., Gleeson, C. M., Russell, S. E., Muzeau, F., Flejou, J. F., Hoang-Xuan, K., Lidereau, R., Thomas, G. \& Hamelin, R. (1998). Determination of the replication error phenotype in human tumors without the requirement for matching normal DNA by analysis of mononucleotide repeat microsatellites. Genes Chromosomes Cancer, 21, (2), pp. 101-107, ISSN 1045-2257

Zhou, Y., Li, N., Zhuang, W. \& Wu, X. (2011). Vascular endothelial growth factor (VEGF) gene polymorphisms and gastric cancer risk in a chinese han population. $\mathrm{Mol}$ Carcinog, 50, (3), pp. 184-188, ISSN 1098-2744

Zwick, A., Munir, M., Ryan, C. K., Gian, J., Burt, R. W., Leppert, M., Spirio, L. \& Chey, W. Y. (1997). Gastric adenocarcinoma and dysplasia in fundic gland polyps of a patient with attenuated adenomatous polyposis coli. Gastroenterology, 113, (2), pp. 659-663, ISSN 0016-5085 


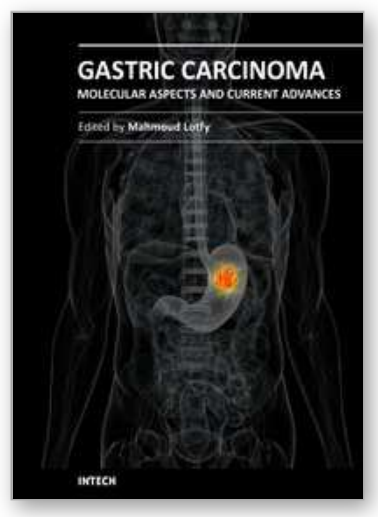

\section{Gastric Carcinoma - Molecular Aspects and Current Advances}

Edited by Prof. Mahmoud Lotfy

ISBN 978-953-307-412-2

Hard cover, 354 pages

Publisher InTech

Published online 15, June, 2011

Published in print edition June, 2011

Gastric cancer is one of the most common tumors worldwide. It has a heterogeneous milieu, where the genetic background, tumor immunology, oxidative stress, and microbial infections are key players in the multiple stages of tumorigenesis. These diverse factors are linked to the prognosis of the gastric cancer and the survival of gastric cancer patients. This book is appropriate for scientists and students in the field of oncology, gastroenterology, molecular biology, immunology, cell biology, biology, biochemistry, and pathology. This authoritative text carefully explains the fundamentals, providing a general overview of the principles followed by more detailed explanations of these recent topics efficiently. The topics presented herein contain the most recent knowledge in gastric cancer concerning the oncogenic signaling, genetic instability, the epigenetic aspect, molecular features and their clinical implications, miRNAs, integrin and E-cadherin, carbohydrateassociated-transferases, free radicals, immune cell responses, mucins, Helicobacter-pylori, neoadjuvant and adjuvant therapy, prophylactic strategy for peritoneal recurrence, and hepatic metastasis.

\section{How to reference}

In order to correctly reference this scholarly work, feel free to copy and paste the following:

Petra Hudler, Matjaz Vogelsang and Radovan Komel (2011). Genetic Instability in Gastric Cancer, Gastric Carcinoma - Molecular Aspects and Current Advances, Prof. Mahmoud Lotfy (Ed.), ISBN: 978-953-307-412-2, InTech, Available from: http://www.intechopen.com/books/gastric-carcinoma-molecular-aspects-and-currentadvances/genetic-instability-in-gastric-cancer

\section{INTECH}

open science | open minds

\section{InTech Europe}

University Campus STeP Ri

Slavka Krautzeka 83/A

51000 Rijeka, Croatia

Phone: +385 (51) 770447

Fax: +385 (51) 686166

www.intechopen.com

\section{InTech China}

Unit 405, Office Block, Hotel Equatorial Shanghai

No.65, Yan An Road (West), Shanghai, 200040, China

中国上海市延安西路65号上海国际贵都大饭店办公楼 405 单元

Phone: +86-21-62489820

Fax: $+86-21-62489821$ 
(C) 2011 The Author(s). Licensee IntechOpen. This chapter is distributed under the terms of the Creative Commons Attribution-NonCommercialShareAlike-3.0 License, which permits use, distribution and reproduction for non-commercial purposes, provided the original is properly cited and derivative works building on this content are distributed under the same license. 